US Army Corps

of Engineers $₫$

Prepared for the U.S. Army Corps of Engineers, Omaha District,

under an Interagency Agreement with the U.S. Department of Energy

Contract DE-AC05-76RL01830

\title{
Methods for Quantifying Shallow- Water Habitat Availability in the Missouri River
}

\section{Final Report}

\author{
TP Hanrahan \\ KB Larson
}

April 2012

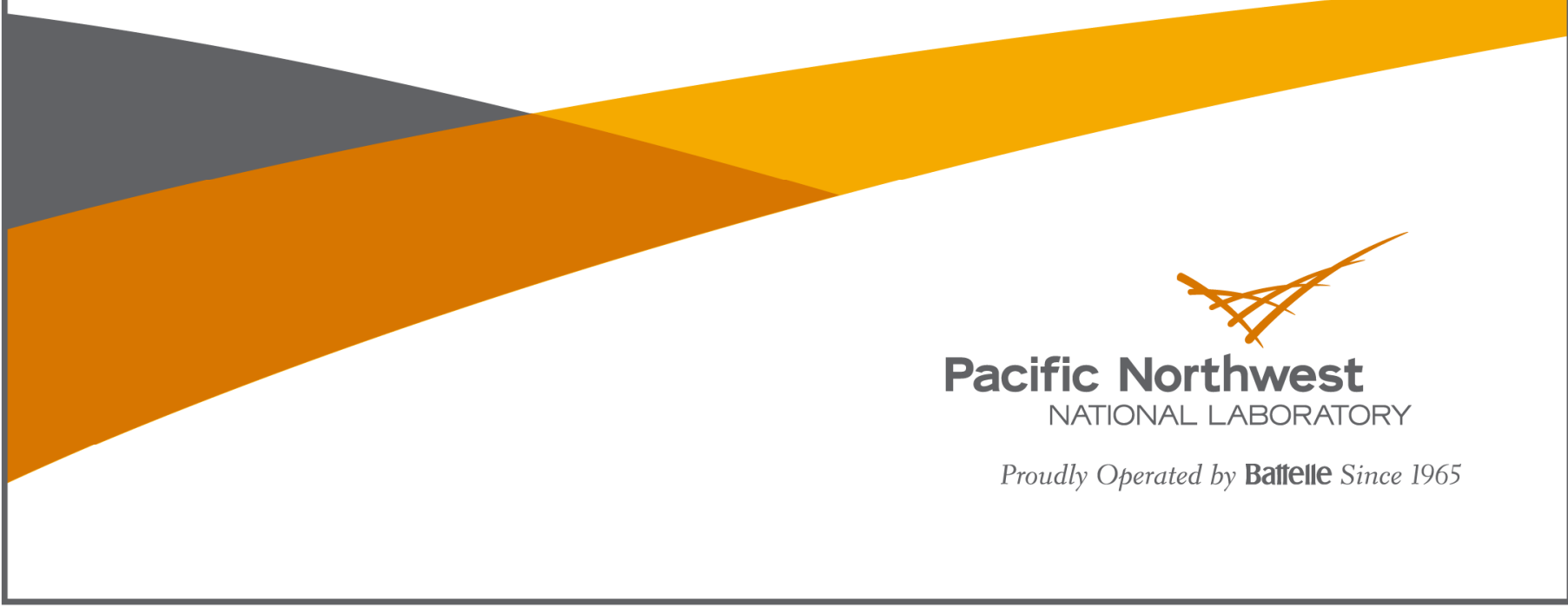




\title{
DISCLAIMER
}

This report was prepared as an account of work sponsored by an agency of the United States Government. Neither the United States Government nor any agency thereof, nor Battelle Memorial Institute, nor any of their employees, makes any warranty, express or implied, or assumes any legal liability or responsibility for the accuracy, completeness, or usefulness of any information, apparatus, product, or process disclosed, or represents that its use would not infringe privately owned rights. Reference herein to any specific commercial product, process, or service by trade name, trademark, manufacturer, or otherwise does not necessarily constitute or imply its endorsement, recommendation, or favoring by the United States Government or any agency thereof, or Battelle Memorial Institute. The views and opinions of authors expressed herein do not necessarily state or reflect those of the United States Government or any agency thereof.

\author{
PACIFIC NORTHWEST NATIONAL LABORATORY \\ operated by \\ BATTELLE \\ for the \\ UNITED STATES DEPARTMENT OF ENERGY \\ under Contract DE-AC05-76RL01830
}

Printed in the United States of America
Available to DOE and DOE contractors from the Office of Scientific and Technical Information,
P.O. Box 62, Oak Ridge, TN 37831-0062;
ph: (865) 576-8401
fax: $(865)$ 576-5728
email: reports@adonis.osti.gov

\begin{abstract}
Available to the public from the National Technical Information Service, U.S. Department of Commerce, 5285 Port Royal Rd., Springfield, VA 22161 ph: (800) 553-6847 fax: $(703) 605-6900$ email: orders@ntis.fedworld.gov online ordering: http://www.ntis.gov/ordering.htm
\end{abstract}

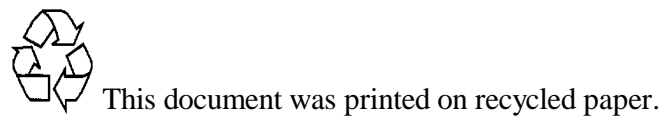




\section{Methods for Quantifying Shallow- Water Habitat Availability in the Missouri River}

\section{Final Report}

TP Hanrahan

KB Larson

April 2012

Prepared for

the U.S. Army Corps of Engineers, Omaha District, under an Interagency Agreement with

the U.S. Department of Energy

Contract DE-AC05-76RL01830

Pacific Northwest National Laboratory

Richland, Washington 99352 



\section{Summary}

As part of regulatory requirements for shallow-water habitat (SWH) restoration, the U.S. Army Corps of Engineers (USACE) completes periodic estimates of the quantity of SWH available throughout the lower $752 \mathrm{mi}$ of the Missouri River. To date, these estimates have been made by various methods that consider only the water depth criterion for SWH. The USACE has completed estimates of SWH availability based on both depth and velocity criteria at four river bends (hereafter called reference bends), encompassing approximately 8 river miles within the lower $752 \mathrm{mi}$ of the Missouri River. These estimates were made from the results of hydraulic modeling of water depth and velocity throughout each bend. Hydraulic modeling of additional river bends is not expected to be completed for deriving estimates of available SWH. Instead, future estimates of SWH will be based on the water depth criterion.

The objective of this project, conducted by the Pacific Northwest National Laboratory for the USACE Omaha District, was to develop geographic information system methods for estimating the quantity of available SWH based on water depth only. Knowing that only a limited amount of water depth and channel geometry data would be available for all the remaining bends within the lower $752 \mathrm{mi}$ of the Missouri River, the intent was to determine what information, if any, from the four reference bends could be used to develop methods for estimating SWH at the remaining bends. Specifically, we examined the relationship between cross-section channel morphology and relative differences between SWH estimates based on combined depth and velocity criteria and the depth-only criterion to determine if a correction factor could be applied to estimates of SWH based on the depth-only criterion. In developing these methods, we also explored the applicability of two commonly used geographic information system interpolation methods (TIN and ANUDEM) for estimating SWH using four different elevation data scenarios. Relative differences in SWH estimates among the four data scenarios were compared to illustrate estimation ranges.

Comparison of depth-only and combined depth and velocity SWH estimates at reference bends indicates that the use of the depth-only criterion may overestimate SWH. Estimates of SWH at reference bends based on depth only were $3.5 \%-12.6 \%$ greater than estimates based on combined depth and velocity criteria, indicating that estimates of SWH based on the depth-only criterion should be reduced by some factor. We attempted to determine whether a categorical factor based on cross-section channel morphology could be used to derive a correction factor for depth-only estimates of SWH. The correction factor was based simply on the percentage difference between estimates of SWH for each bend based on the criteria for depth only and combined depth and velocity. Results of this investigation were inconclusive due to the small sample size of reference bends.

The habitat modeling and channel morphology results suggest that additional information is needed to make accurate estimates of SWH availability throughout the SWH restoration program study area. The four reference bends for which depth, velocity, and channel morphology data are available comprise a very small portion of the SWH restoration program study area and are likely not representative of the remaining bends throughout the study area. The small sample size precludes the ability to develop a SWH correction factor specific to a particular bend channel morphology or hydrologic reach, which would allow estimates of SWH based on depth only to be adjusted to account for the more restrictive SWH criteria that include water velocity with depth. In the absence of such a robust correction factor, it is recommended that the full range of SWH correction factors identified at the four reference bends (i.e., $3.5 \%$ to $12.6 \%$ ) be applied to depth-only estimates of SWH at all bends of interest, to fully capture the 
range of uncertainty associated with the relationship between depth-only and combined depth and velocity estimates of SWH. Applying any SWH correction factor to depth-only estimates of SWH requires that the depth-only estimates themselves be completed as accurately as possible.

Further consideration should be given to the limitations of using the depth-only criterion to estimate SWH and developing appropriate methods to improve such estimates. The latter effort should consider the range of differences between SWH estimates based on the depth-only criterion and combined depth and velocity criteria for a larger proportion of the SWH restoration program area. Additional methods for quantifying SWH should be developed to reflect the U.S. Fish and Wildlife Service expanded definition of SWH, which recognizes the importance of the riverine processes controlling factors that result in a diversity of physical habitat conditions. 


\section{Acronyms and Abbreviations}

2-D

ANUDEM

BiOp

CADD

CRREL

DEM

ESRI

GIS

HAMP

LiDaR

NED

PNNL

RHM

RM

RPA

SWH

TIN

USACE

USFWS

USGS

WSE two-dimensional

a GIS interpolation method

Biological Opinion

computer-aided drafting and design

Cold Regions Research and Engineering Laboratory

digital elevation model

Environmental Systems Research Institute

geographic information system

Habitat Assessment and Monitoring Project

light detection and ranging

National Elevation Dataset

Pacific Northwest National Laboratory

River Habitat Model

river mile(s)

reasonable and prudent alternative

shallow-water habitat

triangulated irregular network (a GIS interpolation method)

U.S. Army Corps of Engineers

U.S. Fish and Wildlife Service

U.S. Geological Survey

water surface elevation 



\section{Contents}

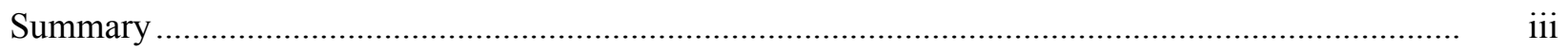

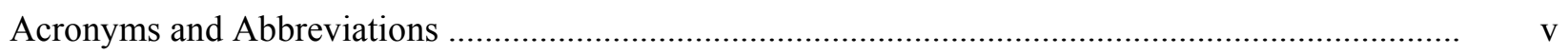

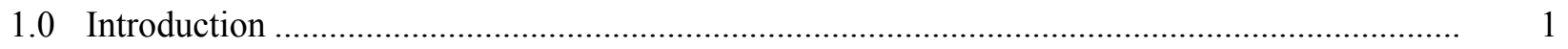

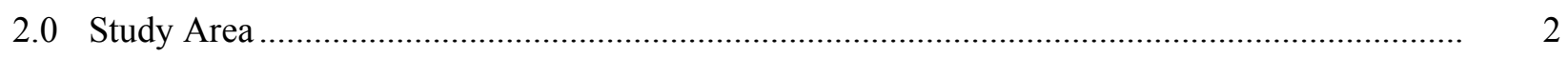

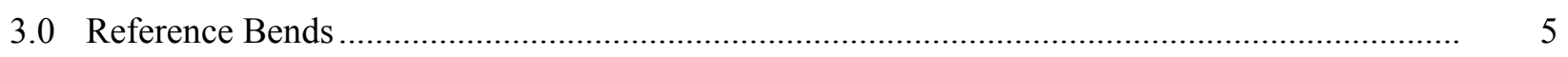

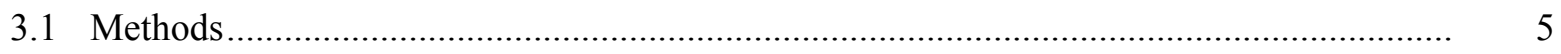

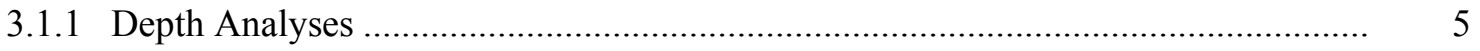

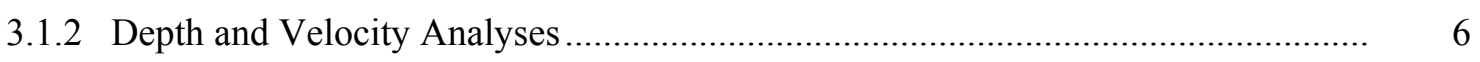

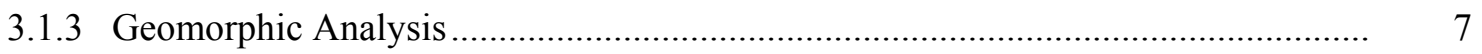

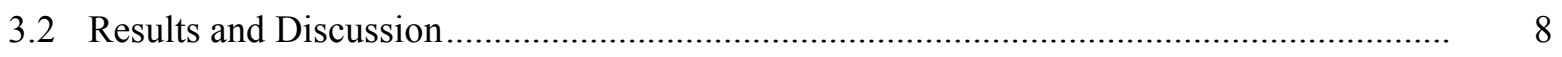

4.0 Habitat Assessment and Monitoring Project Bends .......................................................... 12

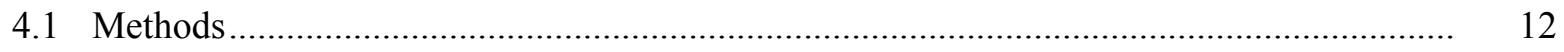

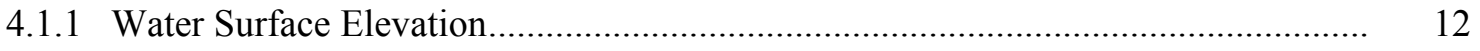

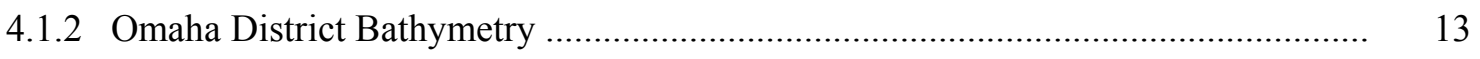

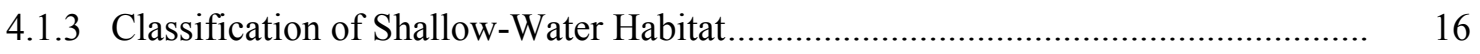

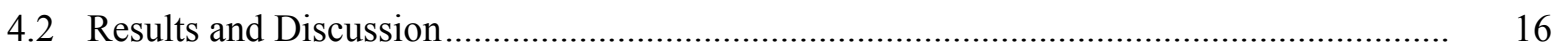

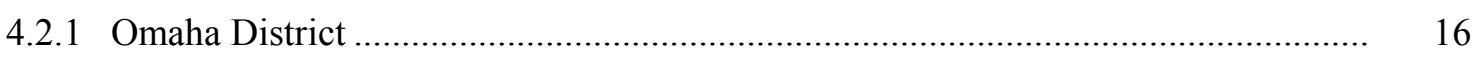

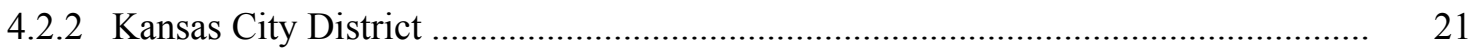

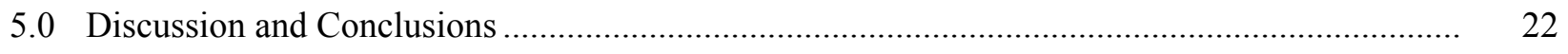

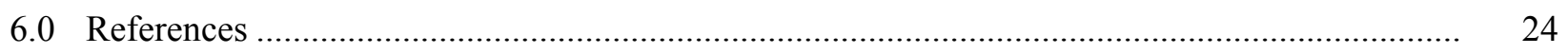




\section{Figures}

1 The USACE shallow-water habitat restoration program encompasses approximately 752 river miles of the lower Missouri River from Ponca, Nebraska, to St. Louis, Missouri

2 The continuum of cross-sectional channel form based on the combination of width to mean depth ratio $F$ and maximum depth to mean depth ratio $d^{*}$....

3 Sample linear relationship between water surface elevation and river mile used to interpolate a water surface elevation surface.

4 Sample TIN and Topo-to-Raster interpolations based on riverbed-only elevations

5 Mean differences in total wetted area between ANUDEM and TIN interpolations based on elevation data scenario.

6 Mean differences in area of shallow-water habitat between ANUDEM and TIN interpolations based on elevation data scenario.

7 Spatial distribution of SWH predicted TIN and ANUDEM interpolations at Pin Hook and Hamburg (right) bends.

\section{Tables}

1 USACE Habitat Assessment and Monitoring Project sampling bends.

2 Hydrologic reaches delineated by the USACE Habitat Assessment and Monitoring Program.

3 Criteria for categorizing cross sections based on $F$ and $d^{*}$.

4 Summary comparison of shallow-water habitat availability based on depth-only criteria at four reference bends

5 Summary comparison of shallow-water habitat availability based on depth and velocity criteria at four reference bends

6 Summary comparison of shallow-water habitat availability based on depth-only and combined depth-velocity criteria.

7 Summary of cross-section channel morphology at the four reference bends

8 Summary of cross-section channel morphology from bends sampled within each of the hydrologic reaches of the lower Missouri River

9 Summary of elevation datasets used to estimate SWH for Omaha District bends

10 Range of SWH estimates based on TIN interpolation for four elevation data scenarios.

11 Range of shallow-water habitat estimates based on ANUDEM interpolation for three elevation data scenarios

12 Summary of shallow-water habitat, non-SWH, and total wetted area at Kansas City District bends 


\subsection{Introduction}

The Missouri River, the longest river in the United States, drains about one-sixth of the contiguous states. Historically, the Missouri was free-flowing and wide. Flooding was common, and the river transported a large amount of sediment, resulting in turbid water. During the 1800 s and $1900 \mathrm{~s}$, the Missouri River was altered to augment navigation, flood control, irrigation, municipal water supply, and power generation. The modifications included dams, channelization, bank stabilization, and removal of large woody debris. These modifications altered the natural hydrology, decreased turbidity, and changed the sediment transport system that created the habitat elements necessary for native flora and fauna to survive. The modifications also altered temperature regimes and reduced the complexity of the habitat.

Within the last century, the upper $1500 \mathrm{mi}$ of the Missouri River have been converted to a series of reservoirs through the placement of dams. Much of the remaining river, including its 735-mi channelized reach between Sioux City, Iowa, and St. Louis, Missouri, has been modified by dikes, rock- or concretearmored banks, and levees. These modifications were made to allow agriculture and other land development within the existing floodplains while also accommodating barge navigation. However, this development also decreased the quantity of shallow-water habitat (SWH) within the river, and reduced the overall habitat diversity for both aquatic and terrestrial biota. In essence, this section of the river has been changed from a shallow, dynamic, highly variable river system into a predominantly deep and swift single channel.

Pallid sturgeon (Scaphirhynchus albus), which have adapted to life in the turbid river systems of the Missouri, Yellowstone, and Mississippi rivers, have declined in numbers to the point where they are in danger of extinction. As a result of the reduced numbers of pallid sturgeon, the species was listed as endangered in 1990. Their decline likely is due to the loss and degradation of their natural habitat as a result of changes in the river's structure and function, as well as the pallid sturgeon's inability to adapt to these changes.

The U.S. Army Corps of Engineers (USACE) provides the primary operational management of the Missouri River and is responsible under the Endangered Species Act of 1973 to take actions within its authorities to conserve listed species. Formal consultation between the U.S. Fish and Wildlife Service (USFWS) and the USACE under Section 7 of the Endangered Species Act of 1973 culminated in issuance of the Biological Opinion on Operation of the Missouri River Main Stem System, Operation and Maintenance of the Missouri River Bank Stabilization and Navigation Project, and Operation of the Kansas River Reservoir System (BiOp; USFWS 2000). The $2000 \mathrm{BiOp}$ found that USACE operations on the Missouri River were likely to jeopardize pallid sturgeon populations unless the reasonable and prudent alternative (RPA) set forth in the BiOp was implemented. After further consultation in 2003 with the Corps, the USFWS issued a Biological Opinion Amendment (USFWS 2003) to modify RPAs described in the $2000 \mathrm{BiOp}$ and provide reasonable and prudent measures to minimize take or harm of pallid sturgeon and describe conservation recommendations that would benefit the species. Implementation of the RPA is achieved through the USACE Missouri River Recovery Program.

The 2003 BiOp Amendment modifications include a requirement for restoring 20\% of the historical quantity of SWH, defined as those areas of the river channel less than $5 \mathrm{ft}$ deep with water velocities less than 2 feet per second $\left(\mathrm{ft} \mathrm{s}^{-1}\right)$. This requirement applies to the lower $752 \mathrm{mi}$ of the Missouri River downstream of Gavins Point Dam and must be met by restoring 20 to $30 \mathrm{ac}$./mi of SWH by the year 2020 . 
Although the BiOp allows for the creation of SWH through channel widening, restoration of chutes and side channels, and flow management, to date the USACE has focused on using construction methods for creating SWH. The construction activities include modifying existing dike structures and constructing adjacent river channel habitat, including chutes and backwater areas.

As part of the BiOp requirements for SWH restoration, the USACE completes periodic estimates of the quantity of SWH available throughout the lower $752 \mathrm{mi}$ of the Missouri River. To date these estimates have been made by various methods that consider only the depth criteria for SWH (i.e., less than $5 \mathrm{ft}$ deep based on the median August discharge). Estimates of SWH availability based on both depth and velocity criteria (velocity less than $2 \mathrm{ft} \mathrm{s}^{-1}$ based on the median August discharge) have been completed at four river bends (hereafter called reference bends), encompassing approximately 8 river miles (RM) within the lower $752 \mathrm{mi}$ of the Missouri River. These estimates are made from the results of hydraulic modeling of water depth and velocity throughout each bend. Hydraulic modeling of additional river bends is not expected to be completed for deriving estimates of available SWH. Instead, future estimates of SWH will be based on the water depth criteria.

The objective of this project was to develop methods for estimating the quantity of available SWH based only on water depth. Knowing that only a limited amount of water depth and channel geometry data would be available for all the remaining bends within the lower $752 \mathrm{mi}$ of the Missouri River, the intent was to determine what information, if any, from the four reference bends could be used to develop methods for estimating SWH at the remaining bends. We sought to identify a SWH correction factor from the reference bends that could be applied to depth-only estimates of SWH at all other river bends. Geomorphic differences among reference bends were considered in determining a SWH correction factor. In developing these methods, we explored the applicability of two commonly used interpolation methods for estimating SWH using four different elevation data scenarios. Relative differences in SWH estimates among the two interpolation methods and four data scenarios were compared to illustrate estimate ranges of SWH.

\subsection{Study Area}

The USACE SWH restoration program encompasses approximately $752 \mathrm{RM}$ of the lower Missouri River from Ponca, Nebraska, to St. Louis, Missouri (Figure 1). Downstream of Sioux City, Iowa (RM 735), the lower Missouri River is highly modified. The original river is trained into a deep, swift channel for barge navigation. Within the lower $735 \mathrm{RM}$ of the Missouri River, channel modifications are being made in order to increase the availability of SWH.

The USACE Habitat Assessment and Monitoring Project (HAMP) was developed to quantify the physical and biological results of SWH creation projects. The HAMP is based on a before-after, controlimpact sampling design in which the sampling unit is defined as a river bend. HAMP sampling is conducted at 44 river bends (Table 1) distributed within five major hydrologic reaches delineated by tributary influence (Table 2). Data on the physical characteristics within some of these bends were used for developing methods to estimate the quantity of available SWH.

The USACE has acquired data and developed hydraulic models at four reference bends: Lower Little Sioux, Civil Upper, Nebraska City, and Rocheport. The data available from these bends encompassed a 
total of approximately 8 RM within hydrologic reaches 1 , 2a, and 4 (Table 1) and were used for evaluating SWH methods based on depth-only criteria and combined depth-velocity criteria. Data from 28 other HAMP bends were used for evaluating SWH methods based on depth-only criteria (Table 1) because the USACE has not completed the hydraulic models for these bends.

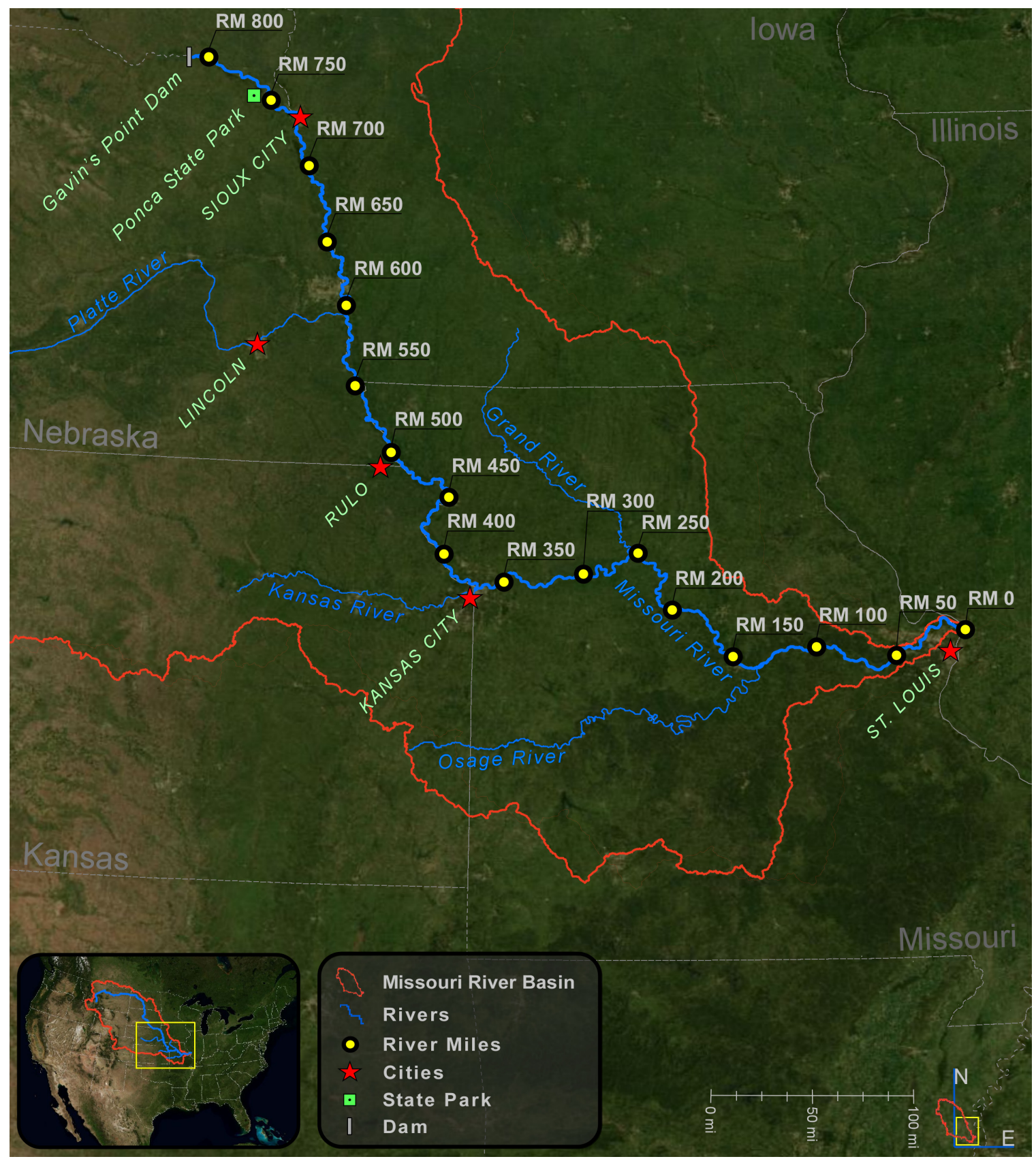

Figure 1. The USACE shallow-water habitat restoration program encompasses approximately 752 river miles of the lower Missouri River from Ponca, Nebraska, to St. Louis, Missouri. 
Table 1. USACE Habitat Assessment and Monitoring Project (HAMP) sampling bends. Water depth data were available for 32 HAMP bends; both depth and velocity data were available within 4 of those bends.

\begin{tabular}{|c|c|c|c|c|}
\hline Bend Name & $\begin{array}{l}\text { River Mile } \\
\text { (upstream) }\end{array}$ & $\begin{array}{c}\text { River Mile } \\
\text { (downstream) }\end{array}$ & Hydrologic Reach & SWH Data \\
\hline Glovers Point Upper & 714.3 & 712.0 & 1 & depth \\
\hline Decatur Lower & 687.4 & 686.0 & 1 & depth \\
\hline Louisville Upper & 686.0 & 683.4 & 1 & depth \\
\hline Little Sioux Upper & 676.3 & 674.8 & 1 & depth \\
\hline Little Sioux Lower & 672.8 & 670.5 & 1 & depth, velocity \\
\hline Peterson Cutoff Lower & 659.2 & 657.8 & 1 & depth \\
\hline Tyson & 655.0 & 651.6 & 1 & depth \\
\hline Desoto Cutoff & 644.8 & 641.8 & 1 & depth \\
\hline Calhoun Lower & 638.5 & 637.3 & 1 & depth \\
\hline Boyer Lower & 636.0 & 634.1 & 1 & depth \\
\hline Tobacco & 589.4 & 586.3 & $2 \mathrm{a}$ & depth \\
\hline Pin Hook & 579.2 & 576.8 & $2 a$ & depth \\
\hline Van Horns & 576.8 & 574.8 & $2 a$ & depth \\
\hline Civil Upper & 574.8 & 572.8 & $2 a$ & depth, velocity \\
\hline Civil Lower A & 572.8 & 571.5 & $2 \mathrm{a}$ & depth \\
\hline Copeland Lower & 565.1 & 562.9 & $2 \mathrm{a}$ & depth \\
\hline Nebraska City & 562.9 & 560.4 & $2 \mathrm{a}$ & depth, velocity \\
\hline Otoe & 556.7 & 555.5 & $2 a$ & depth \\
\hline Hamburg Upper & 555.5 & 552.9 & $2 a$ & depth \\
\hline Barney Upper & 550.5 & 549.5 & $2 \mathrm{a}$ & depth \\
\hline Nemaha & 494.4 & 492.4 & $2 b$ & depth \\
\hline Tarkio & 483.3 & 480.6 & $2 b$ & -- \\
\hline Dallas Upper & 467.0 & 464.5 & $2 b$ & depth \\
\hline Kenmore & 438.7 & 435.2 & $2 b$ & -- \\
\hline Rushville & 428.8 & 425.3 & $2 b$ & -- \\
\hline Latan Upper & 412.1 & 409.9 & $2 b$ & -- \\
\hline Fishing River & 335.3 & 332.4 & 3 & depth \\
\hline Camden & 327.1 & 323.7 & 3 & depth \\
\hline Sni & 321.1 & 319.7 & 3 & depth \\
\hline Baltimore & 304.4 & 301.3 & 3 & -- \\
\hline Malta Lower & 274.0 & 271.8 & 3 & depth \\
\hline Miami Lower & 260.1 & 257.4 & 3 & -- \\
\hline Wilhoite & 234.5 & 232.6 & 4 & -- \\
\hline Robinson Upper & 209.3 & 207.2 & 4 & -- \\
\hline Slaughterhouse & 205.6 & 203.8 & 4 & -- \\
\hline Rocheport & 183.5 & 181.8 & 4 & depth, velocity \\
\hline Searcys & 180.4 & 178.5 & 4 & -- \\
\hline Marion & 162.2 & 159.1 & 4 & depth \\
\hline Isbell & 127.2 & 125.2 & 5 & -- \\
\hline Chamois & 119.1 & 115.9 & 5 & -- \\
\hline Pinckney & 85.5 & 83.0 & 5 & depth \\
\hline Washington & 69.8 & 67.0 & 5 & depth \\
\hline Doziers & 48.6 & 45.4 & 5 & depth \\
\hline Creve Coeur & 31.8 & 28.4 & 5 & depth \\
\hline
\end{tabular}


Table 2. Hydrologic reaches delineated by the USACE Habitat Assessment and Monitoring Program (HAMP).

\begin{tabular}{llccl}
\hline $\begin{array}{l}\text { Hydrologic } \\
\text { Reach }\end{array}$ & \multicolumn{1}{c}{ Reach Description } & $\begin{array}{c}\text { River Mile } \\
\text { (upstream) }\end{array}$ & $\begin{array}{c}\text { River Mile } \\
\text { (downstream) }\end{array}$ & USACE District \\
\hline 1 & Ponca, Nebraska, to Platte River & 752.0 & 594.8 & Omaha \\
2a & Platte River to Rulo, Nebraska & 594.8 & 498.0 & Omaha \\
$2 \mathrm{~b}$ & Rulo, Nebraska, to Kansas River & 498.0 & 367.5 & Kansas City \\
3 & Kansas River to Grand River & 367.5 & 250.0 & Kansas City \\
4 & Grand River to Osage River & 250.0 & 130.2 & Kansas City \\
5 & Osage River to mouth & 130.2 & 0.0 & Kansas City \\
\hline
\end{tabular}

\subsection{Reference Bends}

\subsection{Methods}

Analyses of SWH availability were completed using the geographic information system (GIS) software ArcGIS. GIS-based computation methods used by the USACE were compared with methods developed by Pacific Northwest National Laboratory (PNNL). We used depth and velocity data from the four reference bends to estimate SWH availability with different GIS-based methods. For each of the four reference bends, SWH estimates were completed for two different scenarios: 1) applying the water depth-only criterion $(<5.0 \mathrm{ft})$ and 2$)$ applying the water depth in combination with velocity criteria $\left(<2.0 \mathrm{ft} \mathrm{s}^{-1}\right)$. SWH estimates for these two scenarios would result in a SWH correction factor for each reference bend. SWH estimates at the HAMP bends could then be determined by applying the SWH correction factor to depth-only estimates of SWH at HAMP bends with similar geomorphic characteristics to each of the reference bends. Cross-section channel morphology at each reference bend and HAMP bend was analyzed to identify geomorphic characteristics that could be used to extend the SWH methods from the reference bends to the remaining HAMP bends.

\subsubsection{Depth Analyses}

SWH estimates based on the depth-only criterion were provided to PNNL by the USACE Omaha District (Lower Little Sioux, Civil Upper, and Nebraska City bends) and the Kansas City District (Rocheport bend). The data provided included surface area estimates of suitable SWH, as well as the topographic and water surface elevation data used to derive the estimates of SWH. The Omaha District applied computer-aided drafting and design (CADD) software in its analyses (USACE 2008b), while the Kansas City District applied GIS-based methods (USACE 2008a). The topographic and water surface elevation data were provided to PNNL as text files, which were then used in ArcGIS to create twodimensional (2-D) surfaces of riverbed elevation (bathymetry) and water surface elevation for each bend.

Topographic text files contained point data ( $x$-coordinate, $y$-coordinate) with elevations. These points included riverbed elevations and, in some cases, points along riverbank contour lines. The text files were imported into ArcGIS and converted to point and polyline shapefiles. Using triangulated irregular network (TIN) tools in ArcGIS, we created an empty TIN for each bend. Each TIN was edited by adding the elevation points as mass points from the point elevation shapefile; by adding the contour elevation as 
hard breaklines; and by adding a polygon layer of the bend extent (upstream-downstream) as a softclip layer without elevation. The resulting TIN was converted into a raster surface using the ArcGIS TIN to raster surface tool. The raster cell size (10 ft) was determined based on the density and spatial distribution of the input points. For these data, the appropriate cell size $(p)$ can be estimated to be approximately half of the average spacing between the closest point pairs:

$$
p=0.5 \times \bar{h}_{i j}
$$

where $\bar{h}_{i j}$ is the average distance between two closest point pairs, which is also the mean shortest distance (Hengl 2006). The ArcGIS toolbox Spatial statistics tools/average nearest neighbor with the Euclidean distance method was used to find $\bar{h}_{i j}$. The result of these processing steps was an ArcGIS grid of riverbed and near-channel elevation for each bend.

The USACE provided water surface elevation data for the median August discharge. The spreadsheet data contained selected river mile points with corresponding water surface elevation values. These points were used to interpolate a linearly sloping water surface profile at every one-tenth of a river mile. The resulting text file was imported into ArcGIS and joined with a shapefile containing points every one-tenth of a river mile along the approximate channel centerline. This water surface elevation point shapefile for each bend was used to create an ArcGIS grid of water surface elevation. The ArcGIS grid for each bend was created with the Trend function in Spatial Analyst Tools using the following settings: cell size equal to that of riverbed elevation grid, analysis mask set to that of the riverbed elevation grid, polynomial order equal to 1, and trend method of linear regression. The result of these processing steps was an ArcGIS grid of water surface elevation for the median August discharge at each bend.

Water depth within each bend for the median August discharge was estimated as the difference between the water surface elevation grid and the riverbed elevation grid. Using the map algebra tools in ArcGIS, we calculated a water depth grid by subtracting the riverbed elevation grid from the water surface elevation grid. Suitable SWH based on the depth-only criterion $(<5.0 \mathrm{ft})$ was identified by using the ArcGIS Reclass function to remap all cells of the water depth grid as either suitable or unsuitable. The result of these processing steps was an ArcGIS grid of suitable SWH for the median August discharge at each bend.

\subsubsection{Depth and Velocity Analyses}

The USACE completed 2-D hydraulic modeling at each of the four reference bends. At each point in the 2-D model computational mesh, model results of water depth and velocity for the median August discharge were saved into text files containing the $x$-coordinate, $y$-coordinate, water depth, and water velocity. The USACE used these text files and GIS methods developed by its Cold Regions Research and Engineering Laboratory (CRREL) to estimate SWH availability at each reference bend (CRREL 2008). The text files for each reference bend were provided to PNNL for additional GIS-based calculations of SWH availability and comparison with results from the CRREL methods.

An automated ArcGIS processing model, the River Habitat Model (RHM; Hanrahan et al. 2012) was used to estimate SWH availability from the 2-D hydraulic model output text files. The inputs to RHM are four text files containing the following information: velocity data (xyz format), velocity reclass file 
defining the suitable velocity range, depth data (xyz format), and depth reclass file defining the suitable depth range. The RHM implements the following workflow with the four specified input files:

- xyz files are converted into shapefiles.

- Shapefiles are interpolated into TIN surfaces.

- TIN surfaces are converted into rasters with evenly spaced grid cells.

- Depth and velocity rasters are reclassified to represent suitable and unsuitable values.

- Map algebra is used to calculate an ArcGIS grid representing SWH meeting the combined water depth and water velocity criteria.

Within this workflow, RHM provides several options at each step of the processing. During the TIN creation step, the Perimeter Only option with a maximum edge length of $40 \mathrm{ft}$ was used to limit the TIN interpolation to the empirical elevation data collected from the river channel. All raster layers were interpolated from the TINs using the natural neighbor method and saved as floating point grids. All raster cell sizes $(10 \mathrm{ft})$ were determined using the methodology described above. These processing steps resulted in an ArcGIS grid of suitable SWH for the median August discharge at each bend.

\subsubsection{Geomorphic Analysis}

The ArcGIS grids of riverbed and water surface elevation were used to analyze hydraulic geometry at closely spaced cross sections within the reference bends and HAMP bends. Channel characteristics were extracted from cross sections spaced 0.1 RM apart throughout each bend. At each cross section, the ArcGIS grids of riverbed and water surface elevation were used to calculate the top width, mean depth, and depth at individual stations spaced $10.0 \mathrm{ft}$ apart along a cross section. These data were used to calculate the ratio of width to mean depth $F$ (an index of channel shape) and the ratio of maximum depth to mean depth $d^{*}$ (an index of cross-section asymmetry) for each cross section. When considered simultaneously, these two indices summarize a continuum of cross-sectional channel form that ranges from narrow and deep triangular channels to wide and shallow rectangular channels (Figure 2).

To categorize each cross section within this continuum, we assigned each cross section into one of four categories based on the combined $F$ and $d^{*}$ values (Table 3 ). The definition for each category was facilitated by k-means clustering (Hill and Lewicki 2007) into four classes based on the two variables $F$ and $d^{*}$. Euclidean distances and cluster means were used to help delineate the boundary between classes. Separate $F d^{*}$ category criteria were established for hydrologic reaches 1 and 2 a that differed from reaches $2 \mathrm{~b}, 3,4$, and 5 (Table 3 ).

The $\mathrm{Fd}^{*}$ category and SWH correction factor for each reference bend was examined to identify any relationships between those characteristics. The intent was to identify a correlation between $\mathrm{SWH}$ correction factor and the $F d^{*}$ composition of each reference bend so that the SWH correction factors could be applied to HAMP bends with similar $F d^{*}$ characteristics. 


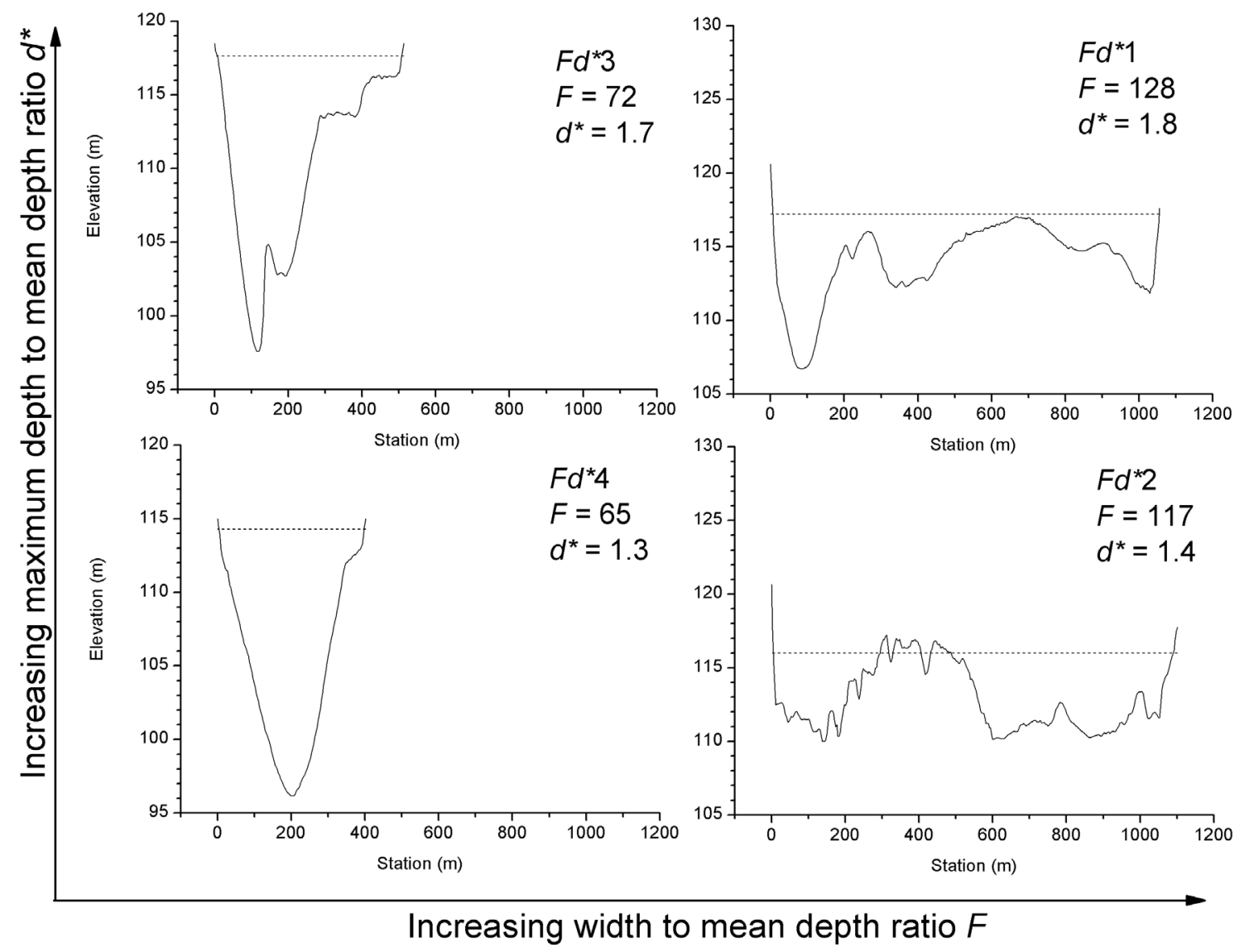

Figure 2. The continuum of cross-sectional channel form based on the combination of width to mean depth ratio $F$ and maximum depth to mean depth ratio $d^{*}$. These cross-section plots of bed elevation (solid line) and water surface elevation (dashed line) for the median August discharge represent the extremes of the $F$ and $d^{*}$ values for the sampled cross sections. All cross sections are plotted at the same scale. The vertical exaggeration is $40 \mathrm{x}$.

\subsection{Results and Discussion}

Estimates of SWH availability based on only the water-depth criterion were very similar among the different methods used. When compared to the Omaha District CADD method, the PNNL method always resulted in lower estimates of SWH availability (Table 4). The SWH estimates for the Omaha District bends resulted in differences between methods ranging from 1.2 ac. at Lower Little Sioux bend to 3.0 ac. at Nebraska City bend. When expressed as a percentage of the total wetted surface area within a bend, these differences range from $0.6 \%$ to $1.3 \%$ (Table 4 ). Comparison between the PNNL method and the Kansas City District method yielded similar results for the Rocheport bend, where SWH estimates differed by 1.7 ac., or $0.7 \%$ of the total wetted bend area (Table 4 ). 
Table 3. Criteria for categorizing cross sections based on $F$ and $d^{*}$.

\begin{tabular}{|c|c|c|}
\hline$F d^{*}$ Category & Definition $^{(a)}$ & Description \\
\hline 1 & $\begin{array}{l}F>=55 \text { and } d^{*}>=1.6 \\
F>=100 \text { and } d^{*}>=1.6\end{array}$ & $\begin{array}{l}\text { Cross section is typically asymmetrical, wide, } \\
\text { with part shallow bar deepening into a v-shaped } \\
\text { deep thalweg }\end{array}$ \\
\hline 2 & $\begin{array}{l}F>=55 \text { and } d^{*}<1.6 \\
F>=100 \text { and } d^{*}<1.6\end{array}$ & $\begin{array}{l}\text { Cross section is symmetrical, wide, and with } \\
\text { relatively uniform shallow depths }\end{array}$ \\
\hline 3 & $\begin{array}{l}F<55 \text { and } d^{*}>=1.6 \\
F<100 \text { and } d^{*}>=1.6\end{array}$ & $\begin{array}{l}\text { Cross section is asymmetrical, narrow, with part } \\
\text { shallow bar deepening into a v-shaped thalweg }\end{array}$ \\
\hline 4 & $\begin{array}{c}F<55 \text { and } d^{*}<1.6 \\
F<100 \text { and } d^{*}<1.6\end{array}$ & $\begin{array}{l}\text { Cross section is symmetrical, narrow, and } \\
\text { relatively uniformly deep }\end{array}$ \\
\hline
\end{tabular}

(a) For each $F d^{*}$ category the first definition applies to hydrologic reaches 1 and 2a (Omaha District bends), while the second definition applies to hydrologic reaches 2b, 3, 4, and 5 (Kansas City District bends).

Table 4. Summary comparison of shallow-water habitat (SWH) availability based on depth-only criteria $(<5.0 \mathrm{ft})$ at four reference bends.

\begin{tabular}{lcccc}
\hline \multirow{2}{*}{ Bend } & \multicolumn{4}{c}{ Shallow-Water Habitat } \\
\cline { 2 - 5 } & PNNL Results (ac.) & Corps Results (ac.) & Difference (ac.) & Difference (\%) $^{(\mathrm{a})}$ \\
\hline Lower Little Sioux & 10.5 & 11.7 & 1.2 & $0.6 \%$ \\
Civil Upper & 12.3 & 13.8 & 1.5 & $0.9 \%$ \\
Nebraska City & 19.7 & 22.8 & 3.0 & $1.3 \%$ \\
Rocheport & 15.0 & 13.3 & 1.7 & $0.7 \%$ \\
\hline
\end{tabular}

(a) This is the difference (ac.) expressed as a percent of the total wetted surface area within a bend.

Estimates of SWH availability based on combined water depth and water velocity criteria were very similar for the different methods used. When compared to the USACE method, the PNNL method always resulted in higher estimates of SWH availability (Table 5). The SWH estimates for all four reference bends resulted in differences between methods ranging from $0.1 \mathrm{ac}$. at Lower Little Sioux bend to 2.7 ac. at Civil Upper bend. When expressed as a percentage of the total wetted surface area within a bend, these differences range from less than $0.1 \%$ to $1.6 \%$ (Table 5 ).

Table 5. Summary comparison of shallow-water habitat $(\mathrm{SWH})$ availability based on depth $(<5.0 \mathrm{ft})$ and velocity $\left(<2.0 \mathrm{ft} \mathrm{s}^{-1}\right)$ criteria at four reference bends.

\begin{tabular}{lcccc}
\hline & \multicolumn{4}{c}{ Shallow-Water Habitat } \\
\cline { 2 - 5 } \multicolumn{1}{c}{ Bend } & PNNL Results (ac.) & $\begin{array}{c}\text { USACE Results } \\
\text { (ac.) }\end{array}$ & Difference (ac.) $\left.^{\text {Difference (\%) }}\right)^{(\mathrm{a})}$ \\
\hline Lower Little Sioux & 8.1 & 8.0 & 0.1 & $0.0 \%$ \\
Civil Upper & 15.8 & 13.0 & 2.7 & $1.6 \%$ \\
Nebraska City & 23.1 & 22.9 & 0.2 & $0.1 \%$ \\
Rocheport & 13.8 & 12.3 & 1.5 & $0.6 \%$ \\
\hline
\end{tabular}

(a) This is the difference (ac.) expressed as a percentage of the total wetted surface area within a bend. 
Within each reference bend, estimates of SWH availability based only on the water depth criterion always resulted in higher estimates of SWH availability than those based on combined water depth and water velocity criteria. These different SWH criteria resulted in marked differences of SWH availability, ranging from $0.8 \mathrm{ac}$. at Nebraska City bend to $1.9 \mathrm{ac}$. at Rocheport bend (Table 6). When expressed as a percentage of the total SWH availability within a bend (i.e., a SWH correction factor), these differences range from $3.5 \%$ to $12.6 \%$ (Table 6 ). These findings are expected, as the inclusion of the water velocity criterion adds another constraint on what is considered suitable SWH.

Table 6. Summary comparison of shallow-water habitat (SWH) availability based on depth-only and combined depth-velocity criteria. Area estimates were made with the PNNL methods.

\begin{tabular}{lcccc}
\hline & \multicolumn{4}{c}{ Shallow-Water Habitat } \\
\cline { 2 - 5 } \multicolumn{1}{c}{ Bend } & Depth Only (ac.) & Depth and Velocity (ac.) & Difference (ac.) & Difference (\%) ${ }^{(\mathrm{a})}$ \\
\hline Lower Little Sioux & 9.3 & 8.1 & 1.2 & $12.6 \%$ \\
Civil Upper & 16.6 & 15.8 & 0.8 & $4.8 \%$ \\
Nebraska City & 24.0 & 23.1 & 0.9 & $3.5 \%$ \\
Rocheport & 15.7 & 13.8 & 1.9 & $11.9 \%$ \\
\hline
\end{tabular}

(a) This is the difference (ac.) expressed as a percentage of the SWH availability estimated with the depth-only criterion.

Cross-section channel morphology differed markedly among the four reference bends. Lower Little Sioux bend comprised approximately $12.5 \%$ of large width-to-depth ratio cross sections $\left(F d^{*} 1\right.$ and $\left.F d^{*} 2\right)$, while the next nearest downstream reference bend (Civil Upper) was composed of only $4.5 \%$ of $F d^{*} 1$ and $F d^{*} 2$ (Table 7). Even within the same hydrologic reach (2a), two of the reference bends contained very different cross-section channel morphology. Civil Upper bend was composed of approximately $95 \%$ of small width-to-depth ratio cross sections $\left(F d^{*} 3\right.$ and $\left.F d^{*} 4\right)$, while Nebraska City bend was composed of approximately $52 \%$ of $F d^{*} 1$ and $F d^{*} 2$ (Table 7).

Table 7. Summary of cross-section channel morphology at the four reference bends.

\begin{tabular}{lcccc}
\hline & \multicolumn{4}{c}{ Cross-Sections Within Each $F d^{*}$ Category (\%) } \\
\cline { 2 - 5 } Bend (hydrologic reach) & $F d^{*} 1$ & $F d^{*} 2$ & $F d^{* 3}$ & $F d^{*} 4$ \\
\hline Lower Little Sioux (1) & 8.3 & 4.2 & 33.3 & 54.2 \\
Civil Upper (2a) & 0.0 & 4.5 & 22.7 & 72.7 \\
Nebraska City (2a) & 26.9 & 34.6 & 15.4 & 23.1 \\
Rocheport (4) & 41.2 & 0.0 & 23.5 & 35.3 \\
\hline
\end{tabular}

Summaries of the SWH correction factors (Table 6) and cross-section channel morphology (Table 7) indicate a lack of correlation between SWH correction factor and channel morphology within each reference bend. The SWH correction factors for both Lower Little Sioux bend (12.6\%) and Rocheport bend (11.9\%) are very similar, but the cross-section channel morphology for each bend is very differentLower Little Sioux bend comprises approximately $12.5 \%$ of large width-to-depth ratio cross sections $\left(F d^{*} 1\right.$ and $\left.F d^{*} 2\right)$, while Rocheport bend comprises $41.2 \%$ of $F d^{*} 1$ and $F d^{*} 2$. Civil Upper bend and 
Nebraska City bend have SWH correction factors within approximately $1 \%$ of each other, yet the combined $F d^{*} 1$ and $F d^{*} 2$ composition of each bend is approximately $4.5 \%$ and $61.5 \%$, respectively (Table 7), indicating very different channel morphology for the two bends. These findings precluded the application of SWH correction factors to HAMP bends based on cross-section channel morphology.

Cross-section channel morphology at the reference bends appeared to be very different from the bends sampled within each hydrologic reach as a whole. For example, Lower Little Sioux bend comprises approximately $12.5 \%$ of large width-to-depth ratio cross sections ( $F d^{*} 1$ and $F d^{*} 2$; Table 7), while the sample from hydrologic reach 1 as a whole is composed of $25 \% F d^{*} 1$ and $F d^{*} 2$ (Table 8). Civil Upper and Nebraska City bends within hydrologic reach 2a were very different from one another (Table 7), and both are very different from the sample of hydrologic reach $2 \mathrm{a}$ as a whole (Table 8). Rocheport bend appears to have somewhat similar channel morphology (Table 7) to the sample from hydrologic reach 4 as a whole (Table 8).

Table 8. Summary of cross-section channel morphology from bends sampled within each of the hydrologic reaches (number of bends sampled ( $n$ ), distance sampled (RM)) of the lower Missouri River.

\begin{tabular}{lcccc}
\hline & \multicolumn{4}{c}{ Cross-Sections Within Each $F d^{*}$ Category $(\%)$} \\
\cline { 2 - 5 } Hydrologic reach $(n, \mathrm{RM})$ & $F d^{*} 1$ & $F d^{*} 2$ & $F d^{* 3}$ & $F d^{* 4}$ \\
\hline $1(10,21.0)$ & 14.3 & 11.1 & 23.0 & 51.6 \\
2a $(10,20.3)$ & 13.3 & 17.1 & 10.4 & 59.2 \\
2b $(2,4.5)$ & 0.0 & 0.0 & 31.9 & 68.1 \\
$3(4,9.9)$ & 31.1 & 7.8 & 28.2 & 33.0 \\
$4(2,4.7)$ & 46.9 & 0.0 & 28.6 & 24.5 \\
$5(4,11.9)$ & 32.2 & 13.2 & 20.7 & 33.9 \\
\hline
\end{tabular}

The four reference bends for which data were provided represent a very small sample of the HAMP bends and a very small distance of the total length of the SWH restoration program study area (752 RM). The reference bends that were sampled represent $2.3 \mathrm{RM}(1.5 \%)$ of hydrologic reach 1, $4.2 \mathrm{RM}(4.3 \%)$ of hydrologic reach $2 \mathrm{a}$, and $1.6 \mathrm{RM}(1.3 \%)$ of hydrologic reach 4 . No combined water depth and water velocity data were provided for bends within hydrologic reaches $2 \mathrm{~b}, 3$, and 5 , representing approximately $378 \mathrm{RM}$ and $50 \%$ of the length of the SWH restoration program study area.

The habitat modeling and channel morphology results suggest that additional information is needed to make accurate estimates of SWH availability throughout the SWH restoration program study area. The four reference bends for which depth, velocity, and channel morphology data are available comprise a very small portion of the SWH restoration program study area and are likely not representative of the remaining bends throughout the study area. The small sample size precludes the ability to develop a SWH correction factor that is specific to a particular bend channel morphology or hydrologic reach, which would allow estimates of SWH based on the depth-only criterion to be adjusted to account for the more restrictive SWH criteria that include water velocity. In the absence of such a robust correction factor, it is recommended that the full range of SWH correction factors identified at the four reference bends (i.e., $3.5 \%$ to $12.6 \%$, Table 4 ) be applied to depth-only estimates of SWH at all bends of interest, to fully capture the range of uncertainty associated with the relationship between depth-only and combined 
depth-velocity estimates of SWH. Applying any SWH correction factor to depth-only estimates of SWH requires that the depth-only estimates themselves be completed as accurately as possible. The analysis of HAMP bends in the Section 4 identifies methods that will foster accurate depth-only estimates of SWH.

\subsection{Habitat Assessment and Monitoring Project Bends}

This section describes methods used to estimate the amount and spatial extent of SWH based on the depth-only criterion ( $\leq 5.0 \mathrm{ft}$ deep) for 20 HAMP bends managed under the jurisdiction of the USACE Omaha District and 12 bends managed by the Kansas City District. The primary objective of this process was to develop a straightforward, repeatable approach for estimating SWH that utilizes commercially available GIS software and tools (ArcMap and ArcToolbox, ESRI, Redlands, California). An additional objective was to assess the variability of SWH estimates for Omaha District bends based on several data scenarios that might be encountered, including riverbed-only and combined riverbed and terrestrial elevation datasets.

\subsection{Methods}

Elevation data sources used in this assessment include riverbed elevations from boat-based sonar surveys, terrestrial breakline elevations, aerial light detection and ranging (LiDaR) elevation data for terrestrial and near-shore aquatic areas, and a digital elevation model (DEM) from the U.S. Geological Survey (USGS) 1/3 arc-second National Elevation Dataset (30-m resolution; http://seamless.usgs.gov/).

The general sequence of steps taken for estimating SWH was to 1) create a water surface elevation (WSE) surface, 2) create a bathymetric surface, 3) subtract the bathymetry surface from the WSE surface to derive water depth surface, 4 ) reclassify the depth surface to represent areas up to $5.0 \mathrm{ft}$ deep (i.e., $\mathrm{SWH}$ ) and greater than $5.0 \mathrm{ft}$ deep (i.e., non-SWH), and 5) apply a correction factor to the SWH estimate based on channel morphology. Steps 1 and 2 for Kansas City District bends were performed by the USACE before this project and therefore are not described in this document. The products of these steps were used by PNNL to perform steps 3 and 4, which were applied in the same manner for all 32 bends. The following sections describe each step. It should be noted that the methods and results for estimating SWH in this document are based on modeled depths at 50\% duration flows. In addition, all geospatial analyses described hereafter were conducted in the coordinate system Universal Transverse Mercator Zone 15 North (units = feet, datum = NAD 1983).

\subsubsection{Water Surface Elevation}

A continuous raster surface of WSE at 50\% duration flow was created for each bend in order to derive a depth surface that could be used to estimate SWH based on the depth-only criterion. Each WSE raster was created using ESRI's Trend tool (Spatial Analyst), which interpolates a smooth linear surface based on a set of sample points. In this case, sample points corresponded to pre-established river mile locations. The WSE at these locations was estimated for every $0.1 \mathrm{RM}$ using a linear fit equation based on measured WSEs provided by the USACE (Figure 3). Measured WSEs were spaced apart approximately $0.5 \mathrm{RM}$. 


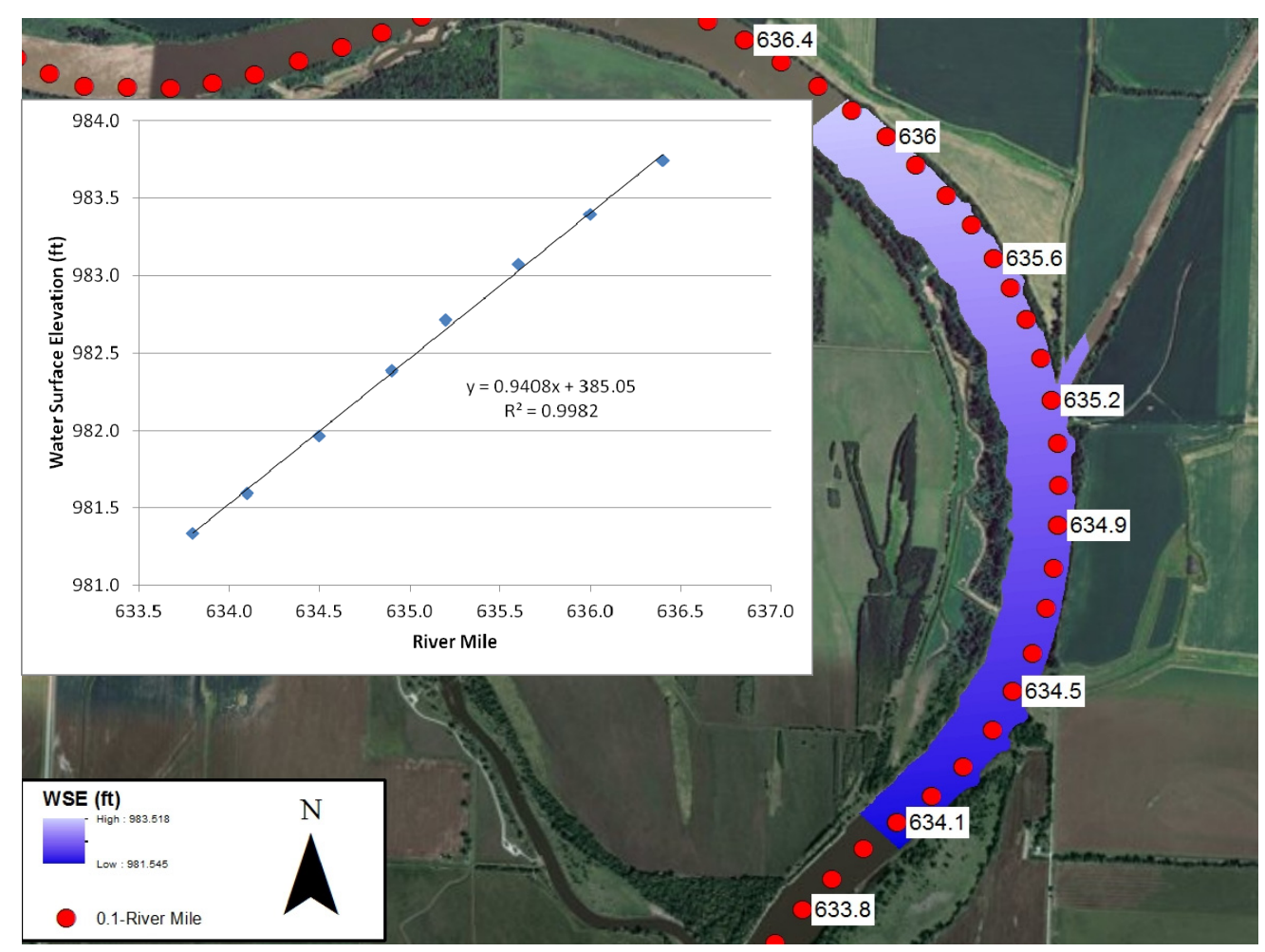

Figure 3. Sample linear relationship between water surface elevation (WSE) and river mile (graph) used to interpolate a water surface elevation surface (map).

\subsubsection{Omaha District Bathymetry}

The bathymetry at Omaha District bends was modeled using four different data scenarios: 1) riverbed-only elevation, 2) combined riverbed and terrestrial breakline elevations, 3) combined riverbed and LiDaR elevations in terrestrial and near-shore aquatic areas, and 4) combined riverbed elevations and National Elevation Dataset (NED) data for adjacent terrestrial areas. Generally, only two to three of these scenarios applied to a given bend due to limited data availability (Table 9). All input datasets, with the exception of NED data, represented measured elevations (in feet) at point-specific locations. NED data, which is provided by the USGS in raster format, was converted to a point vector format (ESRI 3D Analyst) so that it could be merged with riverbed elevations. However, a series of steps had to be taken before this process occurred. First, NED data were re-projected to the correct coordinate system (ESRI Data Management Tools). Next, elevation units were converted from meters to feet by multiplying the raster by a conversion factor (ESRI Spatial Analyst). To extract NED elevations for the non-wetted area to be merged with riverbed elevations, the riverbed-only depth surface had to be interpolated (see Classification of Shallow-Water Habitat). The purpose of this interpolation was to create a surface representing most of the wetted area that could then be used to spatially select and remove NED data that overlapped the river channel.

Two different surface interpolation tools were compared for interpolating bathymetry surfaces for Omaha District bends: the TIN tool and the Topo to Raster tool (both are available in ESRI's 3D Analyst tool suite). These tools were chosen because they are widely applicable and offer different advantages and disadvantages with respect to the data scenarios used in this assessment. Two key advantages of both 
methods are that they allow points to be placed irregularly over a surface, and both are capable of illustrating highly variable surfaces. However, the TIN method is more sensitive to changes in data density due to the manner in which it calculates a surface. The TIN method constructs a vector-based representation of a surface by triangulating a set of vertices (points) and connecting the vertices with a series of edges to form a network of triangles. This surface may then be converted to a raster surface for more efficient viewing and computational purposes. Conversely, the Topo to Raster tool uses an iterative finite difference interpolation technique that combines the surface continuity of global interpolation methods (e.g., splines or kriging) with the computation efficiency of local interpolation methods. This tool is based on the ANUDEM program (Hutchinson 1988, 1989) which was designed specifically for interpolating hydrologically correct DEMs by imposing constraints that ensure a connected drainage structure. Although this design attribute is not necessarily important for interpolating bathymetric surfaces, it provides more flexibility than the TIN method, is computationally more efficient, and provides smoother surfaces. The Topo to Raster tool is referred to as the ANUDEM tool hereafter.

Table 9. Summary of elevation datasets used to estimate SWH for Omaha District bends.

\begin{tabular}{lcccccc}
\hline Bend Name & $\begin{array}{c}\text { Lower Extent } \\
(\mathrm{RM})\end{array}$ & $\begin{array}{c}\text { Upper Extent } \\
(\mathrm{RM})\end{array}$ & $\begin{array}{c}\text { Riverbed- } \\
\text { Only }\end{array}$ & $\begin{array}{c}\text { Riverbed \& } \\
\text { Breakline }\end{array}$ & $\begin{array}{c}\text { Riverbed } \\
\text { \& LiDaR }\end{array}$ & $\begin{array}{c}\text { Riverbed } \\
\text { \& NED }\end{array}$ \\
\hline Barney Upper & 549.5 & 550.5 & -- & $\mathrm{X}$ & -- & $\mathrm{X}$ \\
Boyer Lower & 634.1 & 636.0 & -- & -- & $\mathrm{X}$ & -- \\
Calhoun Lower & 637.3 & 638.5 & -- & -- & $\mathrm{X}$ & -- \\
\hline Civil Lower & 571.5 & 572.8 & $\mathrm{X}$ & -- & -- & $\mathrm{X}$ \\
Civil Upper & 572.8 & 574.8 & $\mathrm{X}$ & $\mathrm{X}$ & -- & $\mathrm{X}$ \\
Copeland Lower & 562.9 & 565.1 & $\mathrm{X}$ & -- & -- & $\mathrm{X}$ \\
Decatur Lower & 686.0 & 687.4 & -- & -- & $\mathrm{X}$ & -- \\
Desoto Cutoff & 641.8 & 644.8 & -- & -- & $\mathrm{X}$ & -- \\
Glovers Point Upper & 712.0 & 714.3 & $\mathrm{X}$ & -- & -- & $\mathrm{X}$ \\
\hline Hamburg Upper & 552.9 & 555.5 & $\mathrm{X}$ & -- & -- & $\mathrm{X}$ \\
Little Sioux Lower & 670.5 & 672.8 & -- & -- & $\mathrm{X}$ & -- \\
Little Sioux Upper & 674.8 & 676.3 & $\mathrm{X}$ & -- & $\mathrm{X}$ & -- \\
Louisville Upper & 683.4 & 686.0 & -- & -- & $\mathrm{X}$ & -- \\
Nebraska City & 560.4 & 562.9 & $\mathrm{X}$ & $\mathrm{X}$ & -- & $\mathrm{X}$ \\
Otoe & 555.5 & 556.7 & $\mathrm{X}$ & -- & -- & $\mathrm{X}$ \\
Peterson Cutoff Lower & 657.8 & 659.2 & -- & -- & $\mathrm{X}$ & -- \\
Pin Hook & 576.8 & 579.2 & $\mathrm{X}$ & -- & -- & $\mathrm{X}$ \\
\hline Tobacco & 586.3 & 589.4 & $\mathrm{X}$ & -- & -- & $\mathrm{X}$ \\
Tyson & 651.6 & 655.0 & -- & -- & $\mathrm{X}$ & -- \\
Van Horns & 574.8 & 576.8 & $\mathrm{X}$ & -- & -- & $\mathrm{X}$ \\
\hline & & & & & & \\
\hline
\end{tabular}

Another key difference between the TIN and ANDUEM tools is the spatial extent in which they interpolate a surface. The TIN method does not interpolate a surface beyond the minimum-bounding extent of the input data, whereas the ANUDEM tool interpolates a surface within the rectangular extent of the input data (regardless of any analysis mask defined in the parameter environments), which results in erroneous values in areas that do not overlap the input data (Figure 4). These areas can be removed later 
by clipping the output raster by a mask layer representing the river channel. However, this creates an extra processing step and may not remove all the spurious data along the shoreline edges where most SWH occurs. Although this problem does not occur with the TIN method, it also has a notable shortcoming with respect to interpolating along the outer edges of the input data. When delineating the TIN area, the user must specify a maximum edge length for the triangulation interpolation. Data points that are farther than this distance will not be considered in the interpolation. Conversely, a too-large maximum edge will result in large flat areas between data points that are far apart. Thus, the user may have to run several iterations for each input dataset to find the appropriate TIN edge length that models an appropriate surface area.

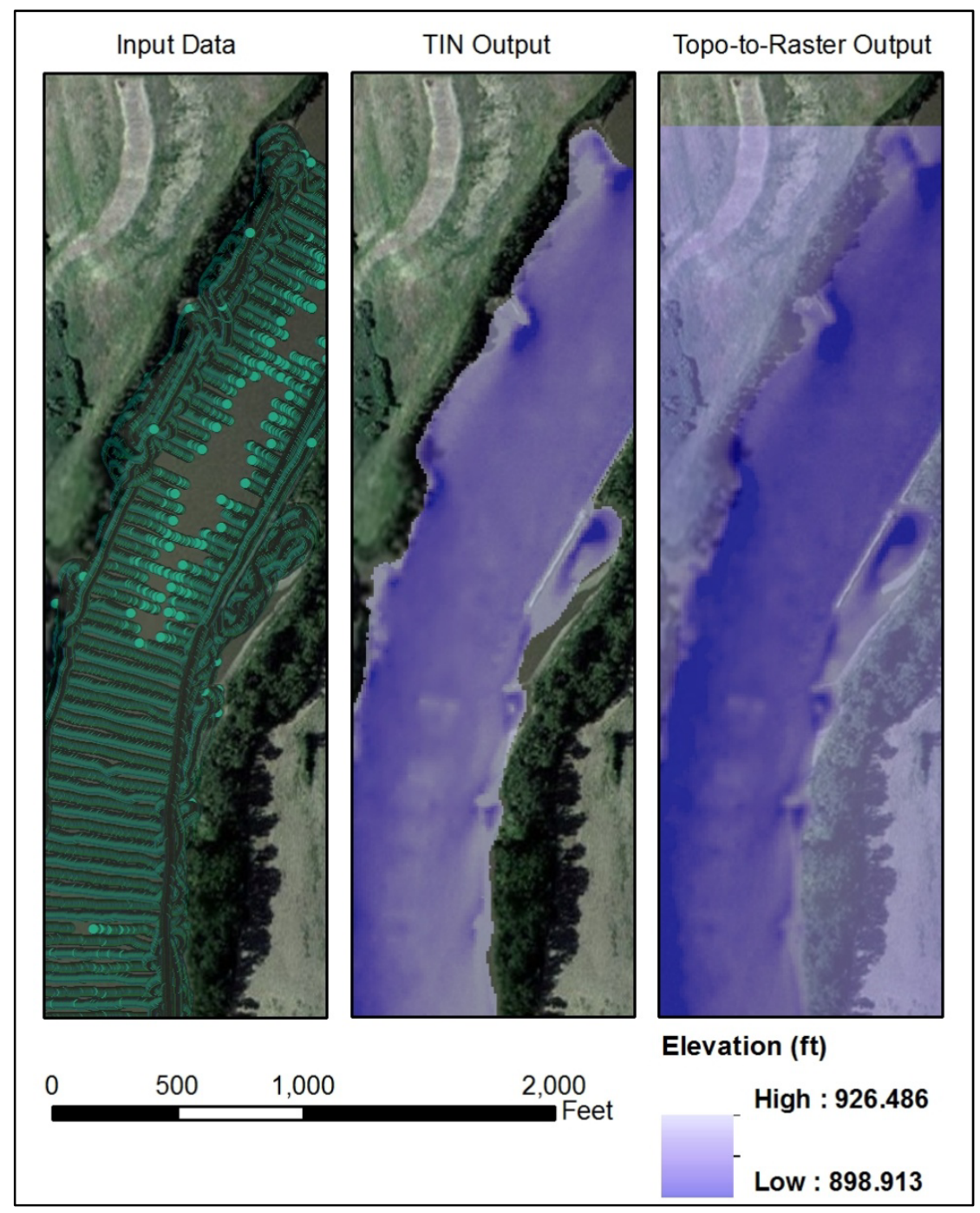

Figure 4. Sample TIN and Topo-to-Raster interpolations based on riverbed-only elevations.

Given these limitations, the ANUDEM tool was applied for only combined riverbed and terrestrial elevation scenarios (i.e., data scenarios 2-4) because these scenarios required clipping outputs to the wetted area, regardless of the interpolation method used. The TIN method was applied to all data scenarios, although considerable experimentation was required to find the appropriate edge length for each bend. 


\subsubsection{Classification of Shallow-Water Habitat}

The following methods apply to both Omaha and Kansas City District bends. To estimate the amount and spatial extent of SWH based on the depth-only criterion (i.e., $\leq 5.0 \mathrm{ft}$ deep), bathymetric surfaces were subtracted from WSE surfaces to derive a water depth surface (ESRI Spatial Analyst). Depth surfaces were reclassified (ESRI Spatial Analyst) into binary rasters representing SWH ( $\leq 5.0 \mathrm{ft}$ deep) and nonSWH ( $>5.0 \mathrm{ft}$ deep). Mask layers were used to restrict these analyses to the officially designated upper and lower river mile extents for each bend. The amount of SWH and non-SWH for each bend was quantified by multiplying the number of cells of each type by the cell size $\left(10 \mathrm{ft} \times 10 \mathrm{ft}=100 \mathrm{ft}^{2}\right)$.

\subsection{Results and Discussion}

The results of the different GIS-based techniques and datasets used to estimate SWH based on the depth-only criterion are summarized here. Results for Omaha and Kansas City District bends are discussed separately due to the different methods and data used to estimate SWH. The section concludes with considerations for conducting GIS-based estimation of SWH using the interpolation methods and elevation datasets presented in this document.

The focus of this section is to 1) present the ranges of SWH estimates for each bend based on the interpolation method and elevation data used and 2) discuss the limitations of each method/dataset with respect to estimating SWH in the lower Missouri River. Although estimates of SWH presented hereafter are based in part on ground-truth data (i.e., boat-based sonar data, $\mathrm{LiDaR}$ ), they have not been assessed for accuracy and should be considered qualitative for the purpose of determining a preferred method for estimating SWH. It is recommended that factors affecting the accuracy of these results be assessed, including 1) the precision of the input data, 2) precision of depth estimates at measured and interpolated locations, and 3) precision of depth estimates based on the resolution in which they were mapped (i.e., $10-\mathrm{ft} \times 10$-ft area).

\subsubsection{Omaha District}

SWH for the 20 Omaha District bends was estimated using two different interpolation techniques (TIN and ANUDEM) for four different data scenarios: 1) riverbed-only elevation (TIN only), 2) combined riverbed and terrestrial breakline elevations, 3) combined riverbed and LiDaR elevations in terrestrial and near-shore aquatic areas, and 4) combined riverbed elevations and NED data for adjacent terrestrial areas. The range of SWH estimates for each data scenario and interpolation method is presented first, followed by a comparison of the relative differences between the two interpolation methods.

\subsubsection{Range of Shallow-Water Habitat Estimates}

Estimates of SWH based on the depth-only criterion varied considerably, depending on the elevation data used in the interpolation. SWH estimates based on TIN interpolation of combined elevation datasets (i.e., riverbed and adjacent terrestrial areas) ranged from 1.0 to 31.5 times more than estimates based on riverbed-only elevations (Table 10), indicating that SWH may be underestimated by using riverbed-only data. The differences in SWH estimates are likely related to the difficulty in surveying shallow areas from a boat and the fact that the TIN does not interpolate beyond the extent of the data. However, this 
result is based on only 11 of the 20 bends, not including Tobacco bend, which contained erroneous NED data that resulted in an overestimation of SWH. Visual comparison of SWH maps based on riverbed NED data to 1-m resolution aerial photography of the river channel indicated that Tobacco was the only bend where there were obvious artifacts in the NED data.

Table 10. Range of SWH estimates (acres) based on TIN interpolation for four elevation data scenarios.

\begin{tabular}{|c|c|c|c|c|}
\hline \multirow[b]{2}{*}{ Bend Name } & \multicolumn{4}{|c|}{ Shallow-Water Habitat (ac.) } \\
\hline & $\begin{array}{l}\text { Riverbed- } \\
\text { Only }\end{array}$ & $\begin{array}{c}\text { Riverbed \& } \\
\text { Breakline }\end{array}$ & $\begin{array}{c}\text { Riverbed \& } \\
\text { NED }\end{array}$ & $\begin{array}{c}\text { Riverbed \& } \\
\text { LiDaR }\end{array}$ \\
\hline Barney Upper & 1.3 & 5.5 & 5.6 & -- \\
\hline Boyer Lower & -- & -- & -- & 12.3 \\
\hline Calhoun Lower & -- & -- & -- & 11.4 \\
\hline Civil Lower & 1.7 & -- & 3.4 & -- \\
\hline Civil Upper & 3.4 & 12.0 & 6.5 & -- \\
\hline Copeland Lower & 5.5 & -- & 9.2 & -- \\
\hline Decatur Lower & -- & -- & -- & 6.1 \\
\hline Desoto Cutoff & -- & -- & -- & 13.1 \\
\hline Glovers Point Upper & 0.0 & -- & 12.0 & -- \\
\hline Hamburg Upper & 0.8 & -- & 6.1 & -- \\
\hline Little Sioux Lower & -- & -- & -- & 11.3 \\
\hline Little Sioux Upper & 1.8 & -- & -- & 7.9 \\
\hline Louisville Upper & -- & -- & -- & 15.5 \\
\hline Nebraska City & 1.3 & 20.0 & 12.6 & -- \\
\hline Otoe & 3.0 & -- & 6.3 & -- \\
\hline Peterson Cutoff Lower & -- & -- & -- & 9.5 \\
\hline Pin Hook & 2.4 & -- & 7.1 & -- \\
\hline Tobacco & 0.5 & -- & $64.7^{(\mathrm{a})}$ & -- \\
\hline Tyson & -- & -- & -- & 20.7 \\
\hline Van Horns & 0.3 & -- & 8.1 & -- \\
\hline
\end{tabular}

(a) SWH was overestimated due to erroneous NED data along a portion of this bend. Visual comparison of SWH maps based on riverbed-NED data to 1-m resolution aerial photography of the river channel indicated that Tobacco was the only bend where there were obvious artifacts in the NED data.

Estimates of SWH also varied, depending on which combined elevation dataset was used. For example, SWH estimates based on TIN interpolations of riverbed-breakline elevations were 1.6-1.8 times greater than riverbed-NED elevations at Civil Upper and Nebraska City bends (Table 10). Similarly, SWH estimates based on ANUDEM interpolations of riverbed-breakline elevations were 1.3-1.5 times greater than riverbed-NED elevations at these bends (Table 11). Conversely, SWH estimates for these two data scenarios were similar at Barney Upper bend regardless of which interpolation method was used. Visual comparison of SWH maps to aerial photography indicates that SWH was overestimated using riverbed-breakline data at Civil Upper and Nebraska City bends but not at Barney Upper. Despite these differences, it is difficult to draw any conclusions as to which combined elevation dataset is more appropriate because there were only three bends for which this comparison 
could be made. However, the availability and enhanced coverage of NED data make it an appealing choice compared to collecting breakline information.

Estimates of SWH based on riverbed-LiDaR data could not be compared to those for other data scenarios because riverbed data was not provided separately for these bends, nor could it be extracted easily from the combined datasets without considerable manual labor. Visual comparison of SWH maps to aerial photography indicated that riverbed-LiDaR interpolations provided accurate coverage of the river channel. Most important, the addition of LiDaR to riverbed data improved coverage in near-shore areas where most SWH occurs.

Table 11. Range of shallow-water habitat estimates (acres) based on ANUDEM interpolation for three elevation data scenarios.

\begin{tabular}{|c|c|c|c|}
\hline \multirow[b]{2}{*}{ Bend Name } & \multicolumn{3}{|c|}{ Shallow-Water Habitat $(\mathrm{ac},)^{(\mathrm{a})}$} \\
\hline & $\begin{array}{c}\text { Riverbed \& } \\
\text { Breakline }\end{array}$ & $\begin{array}{c}\text { Riverbed \& } \\
\text { NED }\end{array}$ & $\begin{array}{c}\text { Riverbed \& } \\
\text { LiDaR }\end{array}$ \\
\hline Barney Upper & 5.1 & 5.2 & -- \\
\hline Boyer Lower & -- & -- & 12.0 \\
\hline Calhoun Lower & -- & -- & 12.5 \\
\hline Civil Lower & -- & 5.1 & -- \\
\hline Civil Upper & 11.2 & 8.4 & -- \\
\hline Copeland Lower & -- & 11.2 & -- \\
\hline Decatur Lower & -- & -- & 6.4 \\
\hline Desoto Cutoff & -- & -- & 12.5 \\
\hline Glovers Point Upper & -- & 12.7 & -- \\
\hline Hamburg Upper & -- & 9.0 & -- \\
\hline Little Sioux Lower & -- & -- & 12.1 \\
\hline Little Sioux Upper & -- & -- & 8.5 \\
\hline Louisville Upper & -- & -- & 16.2 \\
\hline Nebraska City & 20.9 & 13.6 & -- \\
\hline Otoe & -- & 7.5 & -- \\
\hline Peterson Cutoff Lower & -- & -- & 9.8 \\
\hline Pin Hook & -- & 9.4 & -- \\
\hline Tobacco & -- & $64.5^{(\mathrm{b})}$ & -- \\
\hline Tyson & -- & -- & 20.8 \\
\hline Van Horns & -- & 8.9 & -- \\
\hline \multicolumn{4}{|c|}{$\begin{array}{l}\text { (a) ANUDEM interpolation was not conducted for the riverbed-only data } \\
\text { scenario (see Methods section). } \\
\text { (b) SWH was overestimated due to erroneous NED data along a portion of } \\
\text { this bend. }\end{array}$} \\
\hline
\end{tabular}

\subsubsection{Comparison of Interpolation Methods}

TIN and ANUDEM interpolation methods were compared to assess differences in the way they predicted depth and, ultimately, SWH for the three combined elevation data scenarios (ANUDEM interpolation was not conducted using riverbed-only data). These differences were expressed qualitatively by calculating differences in the total wetted area (at 50\% duration flow) and total area of 
SWH. Differences in the total wetted area were compared between interpolation methods because it may be an indicator that one method predicts depth differently from the other (i.e., deeper or shallower), particularly in near-shore areas where elevation is interpolated from aquatic and terrestrial elevations. A more direct comparison of depth surfaces would be to subtract one surface from another (i.e., subtract depths at each pixel location) and summarize the differences statistically. However, this comparison would omit areas where the two surfaces do not overlap, which in this case is primarily along the shoreline where most SWH typically occurs. Differences in the total area of SWH were compared between interpolation methods as a further means to assess how they affect estimation of depth and ultimately SWH.

Differences in total wetted area varied between the two interpolation methods, depending on the type of elevation data used (Figure 5). Total wetted areas based on ANUDEM interpolation of riverbedbreakline $(N=3)$ and riverbed NED data $(N=11)$ were 0.6 and 2.2 ac. greater on average, respectively, than those based on TIN interpolation. In contrast, total wetted areas based on ANDUEM interpolation of riverbed LiDaR data $(N=9)$ were 0.7 ac. less on average than those based on TIN interpolation. Estimates of SWH predicted by TIN and ANUDEM interpolation did not vary significantly among data scenarios (Figure 6), indicating that interpolation method had less of an effect on estimation of SWH than it did on total wetted area. Overall, differences in SWH between the two interpolation methods ranged from 0.4 to 2.9 ac.

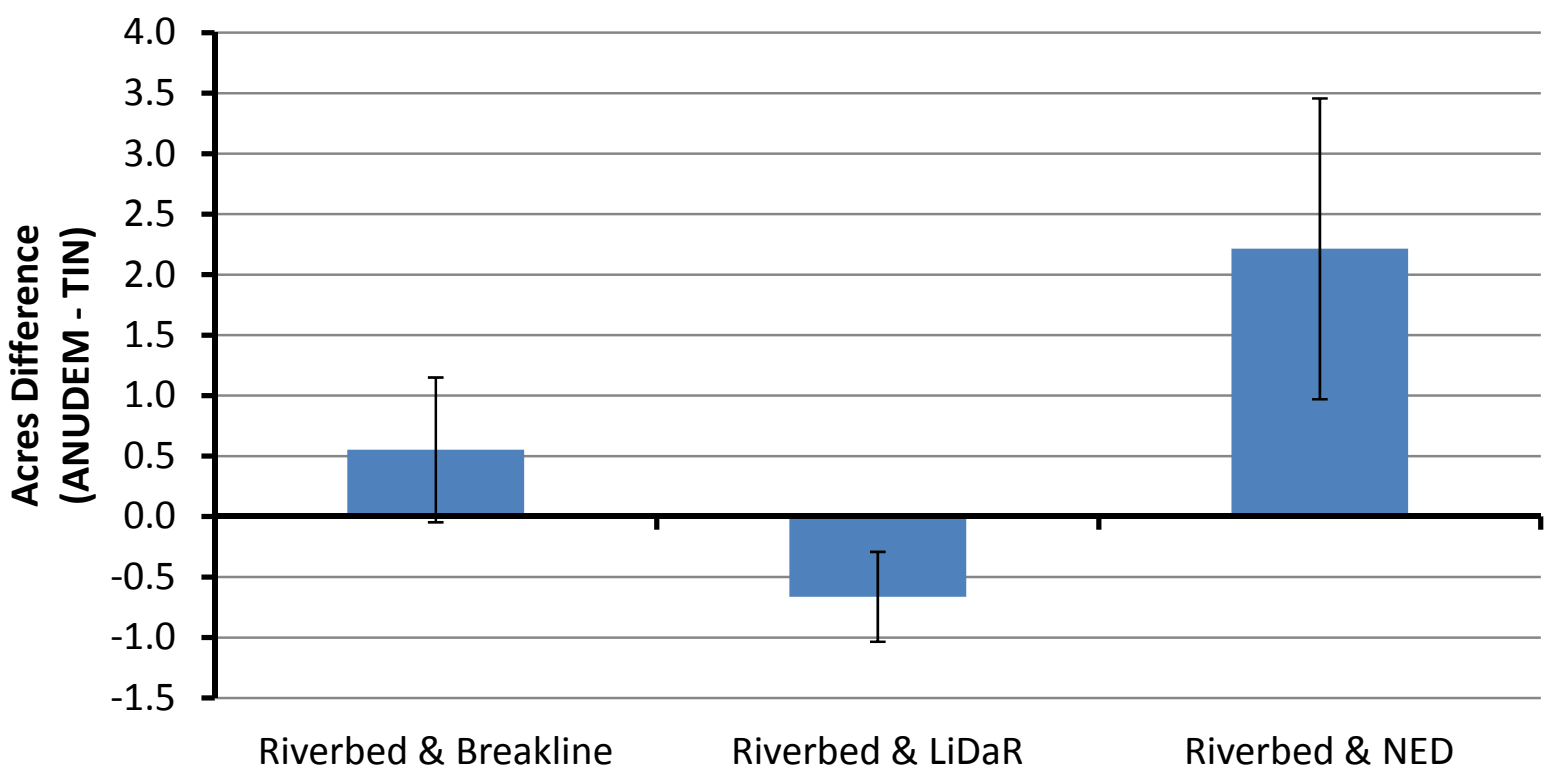

Figure 5. Mean differences ( $\pm 1 \mathrm{SD}$ ) in total wetted area between ANUDEM and TIN interpolations based on elevation data scenario. 


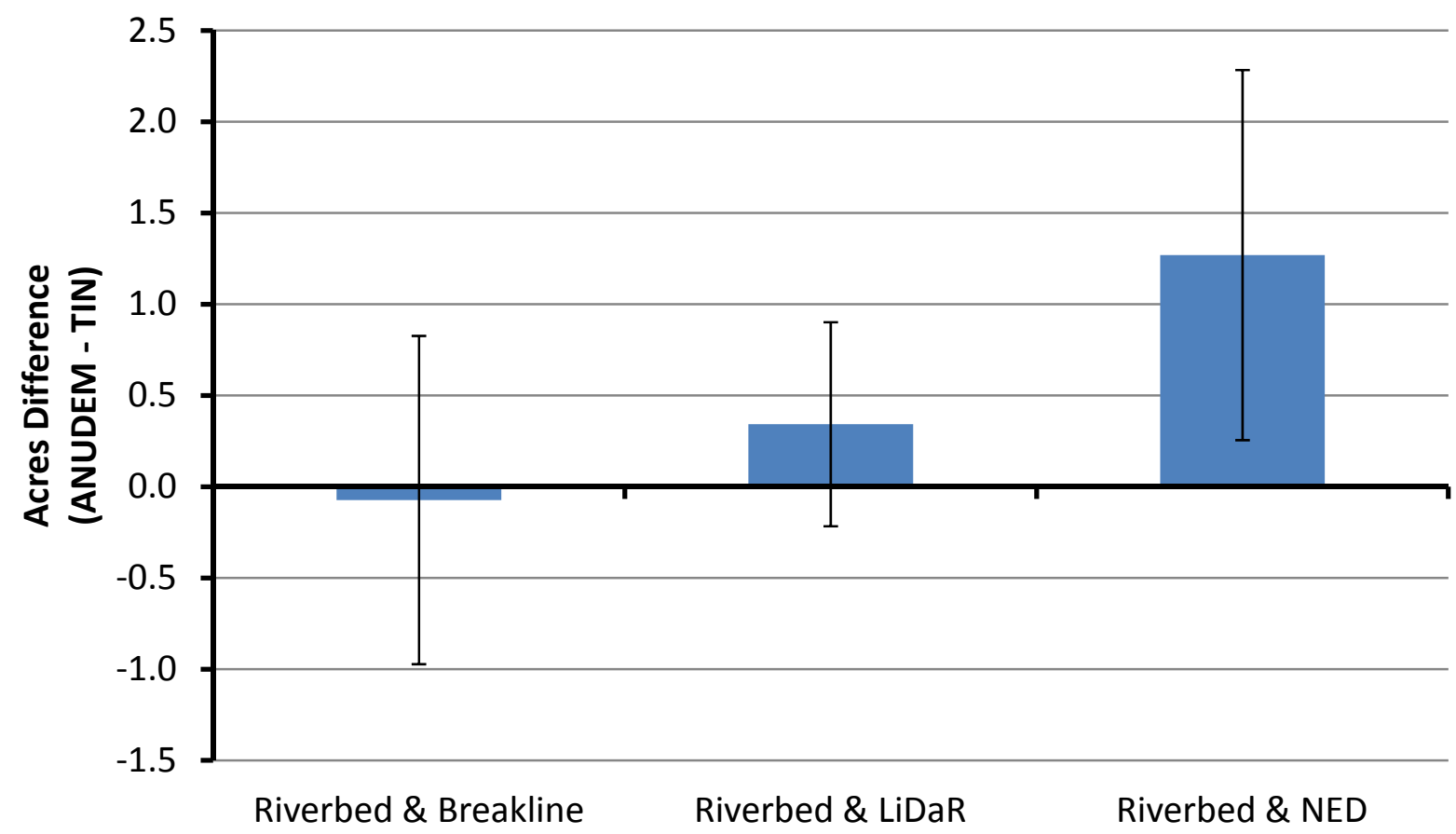

Figure 6. Mean differences ( $\pm 1 \mathrm{SD})$ in area of shallow-water habitat $(\mathrm{SWH})$ between ANUDEM and TIN interpolations based on elevation data scenario.

Comparison of total wetted areas indicated that the choice of interpolation method could affect bathymetry, depending on the type of input data that is used. However, both interpolation methods yielded similar estimates of SWH. This could suggest that the spatial distribution of SWH may differ between TIN and ANUDEM interpolations (e.g., occurred at a higher/lower elevation). However, we found little evidence of such discourse between interpolation methods when we compared maps of SWH. For example, the spatial distribution of SWH predicted by TIN and ANUDEM interpolations corresponded very closely at Hamburg and Pin Hook bends, which had the greatest disparity in SWH between TIN and ANUDEM outputs (Figure 7). 


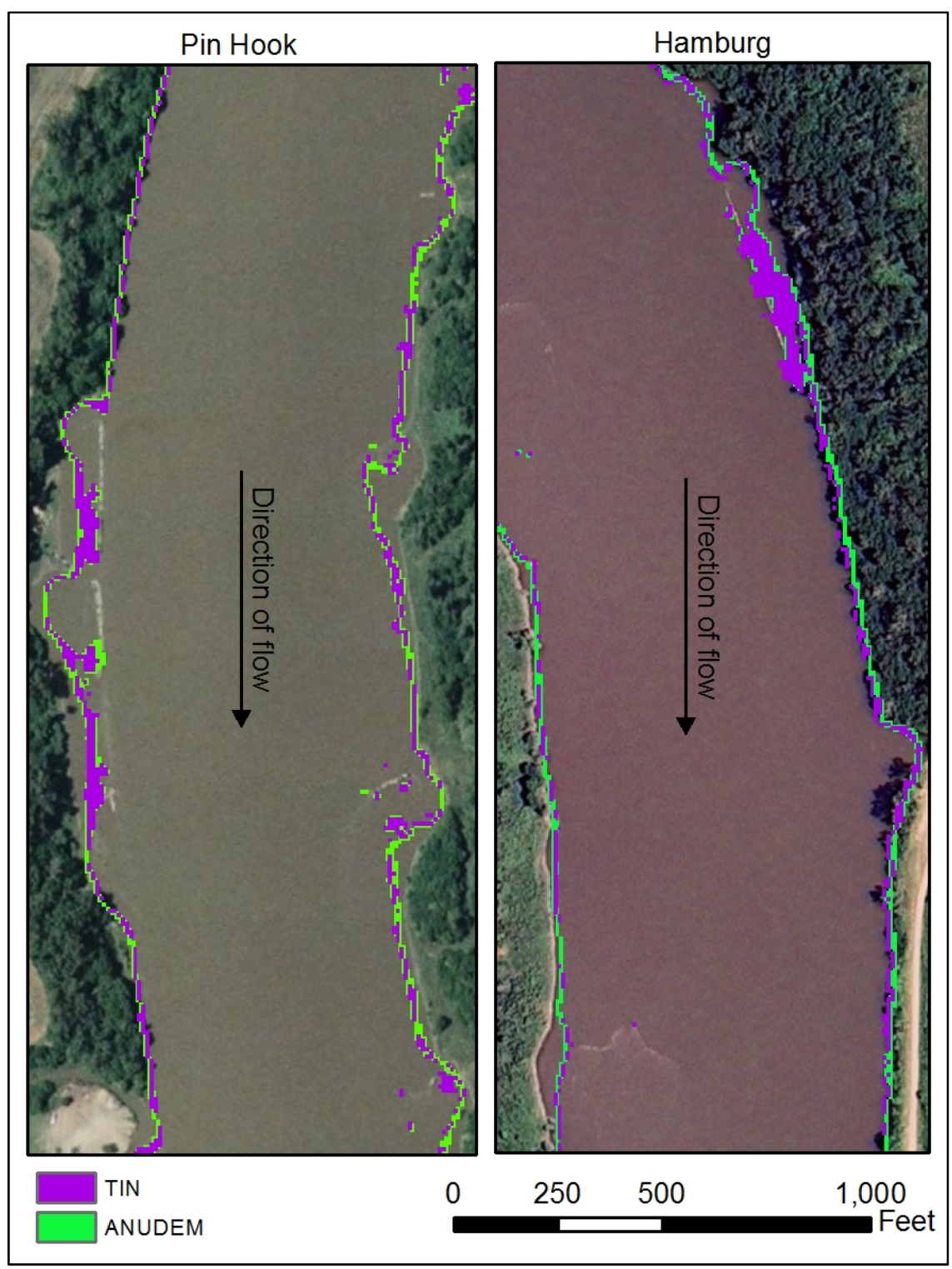

Figure 7. Spatial distribution of SWH predicted TIN and ANUDEM interpolations at Pin Hook (left) and Hamburg (right) bends.

\subsubsection{Kansas City District}

The following summarizes estimates of SWH at Kansas City District bends. Classification of depth surfaces to estimate SWH was conducted in the same manner as for Omaha District bends, although Kansas City depth surfaces were based on bathymetry and WSE surfaces provided by the USACE. Therefore, no comparisons of elevation data or interpolation method were made. The amount of SWH at Kansas City bends ranged from 0.1 to 1.1 ac./bend (Table 12). 
Table 12. Summary of shallow-water habitat (SWH), non-SWH, and total wetted area at Kansas City District bends.

\begin{tabular}{lccccc}
\hline Bend Name & $\begin{array}{c}\text { Lower Extent } \\
\text { (RM) }\end{array}$ & $\begin{array}{c}\text { Upper Extent } \\
(\mathrm{RM})\end{array}$ & SWH (ac.) & $\begin{array}{c}\text { Non-SWH } \\
\text { (ac.) }\end{array}$ & $\begin{array}{c}\text { Total Wetted } \\
\text { Area (ac.) }\end{array}$ \\
\hline Camden & 323.7 & 327.1 & 0.5 & 4.1 & 4.6 \\
Creve Coeur & 28.4 & 31.8 & 1.1 & 4.6 & 5.7 \\
Dallas Upper & 464.5 & 467.0 & 0.2 & 2.2 & 2.4 \\
Doziers & 45.4 & 48.6 & 0.5 & 3.7 & 4.2 \\
Fishing River & 332.4 & 335.3 & 0.5 & 3.0 & 3.5 \\
Malta Lower & 271.8 & 274.0 & 0.5 & 2.2 & 2.7 \\
Marion & 159.1 & 162.2 & 0.9 & 3.8 & 4.8 \\
Nemaha & 492.4 & 494.4 & 0.1 & 1.6 & 1.7 \\
Pinckney & 83.0 & 85.5 & 0.5 & 3.3 & 3.8 \\
Rocheport & 181.8 & 187.2 & 0.1 & 2.5 & 2.6 \\
Sni & 319.7 & 321.1 & 0.1 & 1.7 & 1.8 \\
Washington & 67.0 & 69.8 & 0.4 & 3.8 & 4.3 \\
\hline
\end{tabular}

\subsection{Discussion and Conclusions}

The objective of this project was to develop methods for estimating the quantity of available SWH based only on water depth. Knowing that only a limited amount of water depth and channel geometry data would be available for all the remaining bends within the lower $752 \mathrm{mi}$ of the Missouri River, the intent was to determine what information, if any, from the four reference bends could be used to develop methods for estimating SWH at the remaining bends. Specifically, we examined the relationship between cross-section channel morphology $\left(F d^{*}\right)$ and relative differences between SWH estimates based on criteria for combined depth and velocity and depth only to determine if a correction factor could be applied to estimates of SWH based on the depth-only criterions. In developing these methods, the applicability of two commonly used interpolation methods (TIN and ANUDEM) were also explored for estimating SWH using four different elevation data scenarios. Relative differences in SWH estimates among the four data scenarios were compared to illustrate estimation ranges.

Comparison of depth-only and combined depth and velocity SWH estimates at reference bends indicates that the use of the depth-only criterions may overestimate $\mathrm{SWH}$ as it is defined in the $2003 \mathrm{BiOp}$ (i.e., water depths $\leq 5.0 \mathrm{ft}$ and water velocities $\leq 2.0 \mathrm{ft} \mathrm{s}^{-1}$ ). Estimates of SWH at reference bends based on the depth-only criterion were $3.5 \%-12.6 \%$ greater than estimates based on combined depth and velocity criteria, indicating that estimates of SWH based on the depth-only criterion should be reduced by some factor. However, this finding is based on a small sample size of bends and may not apply to the entire SWH restoration program area. Further study of this effect with a larger sample size of bends is recommended to assess the range of variability of the percentage difference between depth-only and combined depth and velocity estimates to determine an appropriate method to correct estimates of SWH based only on water depth. 
We attempted to determine whether a categorical factor based on cross-section channel morphology $\left(F d^{*}\right)$ could be used to derive a correction factor for depth-only estimates of SWH. The correction factor was based simply on the percentage difference between estimates of SWH for each bend based on depthonly and combined depth and velocity criteria. Results of this investigation were inconclusive because of the small sample size of reference bends.

The habitat modeling and channel morphology results suggest that additional information is needed to make accurate estimates of SWH availability throughout the SWH restoration program study area. The four reference bends for which depth, velocity, and channel morphology data are available comprise a very small portion of the SWH restoration program study area and are likely not representative of the remaining bends throughout the study area. The small sample size precludes the ability to develop a SWH correction factor specific to a particular bend channel morphology or hydrologic reach, which would allow estimates of SWH based on depth only to be adjusted to account for the more restrictive SWH criteria that include water velocity. In the absence of such a robust correction factor, it is recommended that the full range of SWH correction factors identified at the four reference bends (i.e., $3.5 \%$ to $12.6 \%$ ) be applied to depth-only estimates of SWH at all bends of interest, to fully capture the range of uncertainty associated with the relationship between depth-only and combined depth/velocity estimates of SWH. Applying any SWH correction factor to depth-only estimates of SWH requires that the depth-only estimates themselves be completed as accurately as possible.

Comparison of TIN and ANUDEM interpolation methods for 20 bends in the Omaha District indicated that both methods provided similar estimates of SWH when combined riverbed and terrestrial elevation data were used. The ANUDEM tool was more efficient to use than the TIN tool, except when dealing only with riverbed data.

Use of only riverbed elevations may underestimate the amount of SWH considerably at some locations. This problem is likely because it is difficult to survey areas shallower than $5 \mathrm{ft}$ from a boat. Therefore, it is recommended that riverbed elevation data be combined with elevation data for the adjacent terrestrial area to improve interpolation of the elevation surface near the shoreline where most SWH occurs. This can be accomplished relatively inexpensively and easily by acquiring digital elevation model data from one of the USGS national elevation datasets. However, errors in this data can occur, as evidenced at Tobacco bend in this study.

In summary, further consideration should be given to the limitations of using the depth-only criterion to estimate SWH and developing appropriate methods to improve such estimates. The latter effort should consider the range of differences between SWH estimates based on depth only and combined depth and velocity criteria for a larger proportion of the SWH restoration program area. Additional methods for quantifying SWH should be developed to reflect the USFWS expanded definition of SWH, which recognizes the importance of the riverine processes controlling factors that result in a diversity of physical habitat conditions. 


\subsection{References}

Endangered Species Act of 1973. 1973. Public Law 93-205, as amended, 16 USC 1531 et seq.

CRREL. 2008. Shallow water habitat tools for ArcMap. Office Report, February 2008. Cold Regions

Research and Engineering Laboratory, U.S. Army Corps of Engineers, Omaha District, Omaha, Nebraska.

Hanrahan TP, TE Seiple, and JW Lettrick. 2012. PNNL River Habitat Model User Guide.

PNNL-21048, Pacific Northwest National Laboratory, Richland, Washington.

Hengl T. 2006. Finding the right pixel size. Computers and Geosciences 32:1283-1298.

Hill T and P Lewicki. 2007. Statistics: Methods and Applications. StatSoft, Inc., Tulsa, Oklahoma.

Hutchinson MF. 1988. Calculation of hydrologically sound digital elevation models. In Third Symposium on Spatial Data Handling, pp. 117-133, International Geography Union, Sydney, Australia.

Hutchinson MF. 1989. A new procedure for gridding elevation and stream line data with automatic removal of spurious pits. Journal of Hydrology 106:211-232.

USACE. 2008a. Instructions for creating depth maps. Office Report, January 2008. U.S. Army Corps of Engineers, Kansas City District, Kansas City, Missouri.

USACE. 2008b. Missouri River shallow water habitat compliance review. Office Report, January 2008. U.S. Army Corps of Engineers, Omaha District, Omaha, Nebraska.

USFWS. 2000. Biological Opinion on the Operation of the Missouri River Main Stem Reservoir System, Operation and Maintenance of the Missouri River Bank Stabilization and Navigation Project, and Operation of the Kansas River Reservoir System. U.S. Fish and Wildlife Service, Minneapolis, Minnesota.

USFWS. 2003. 2003 Amendment to the 2000 Biological Opinion on the Operation of the Missouri River Main Stem Reservoir System, Operation and Maintenance of the Missouri River Bank Stabilization and Navigation Project, and Operation of the Kansas River Reservoir System. U.S. Fish and Wildlife Service, Minneapolis, Minnesota. 



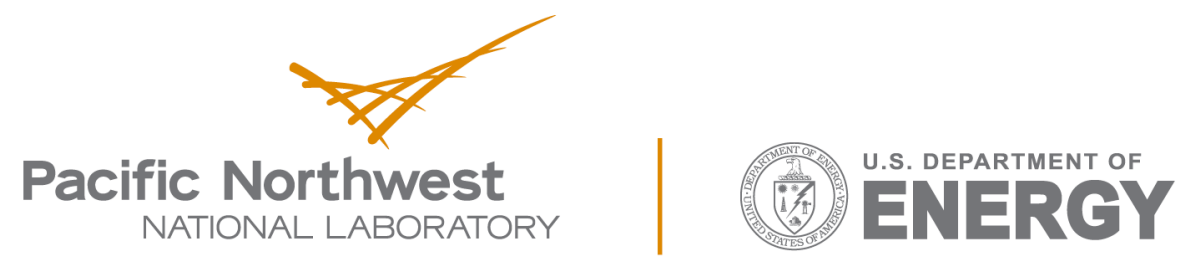

Proudly Operated by Battelle Since 1965

902 Battelle Boulevard

P.O. Box 999

Richland, WA 99352

1-888-375-PNNL (7665)

www.pnnl.gov 